
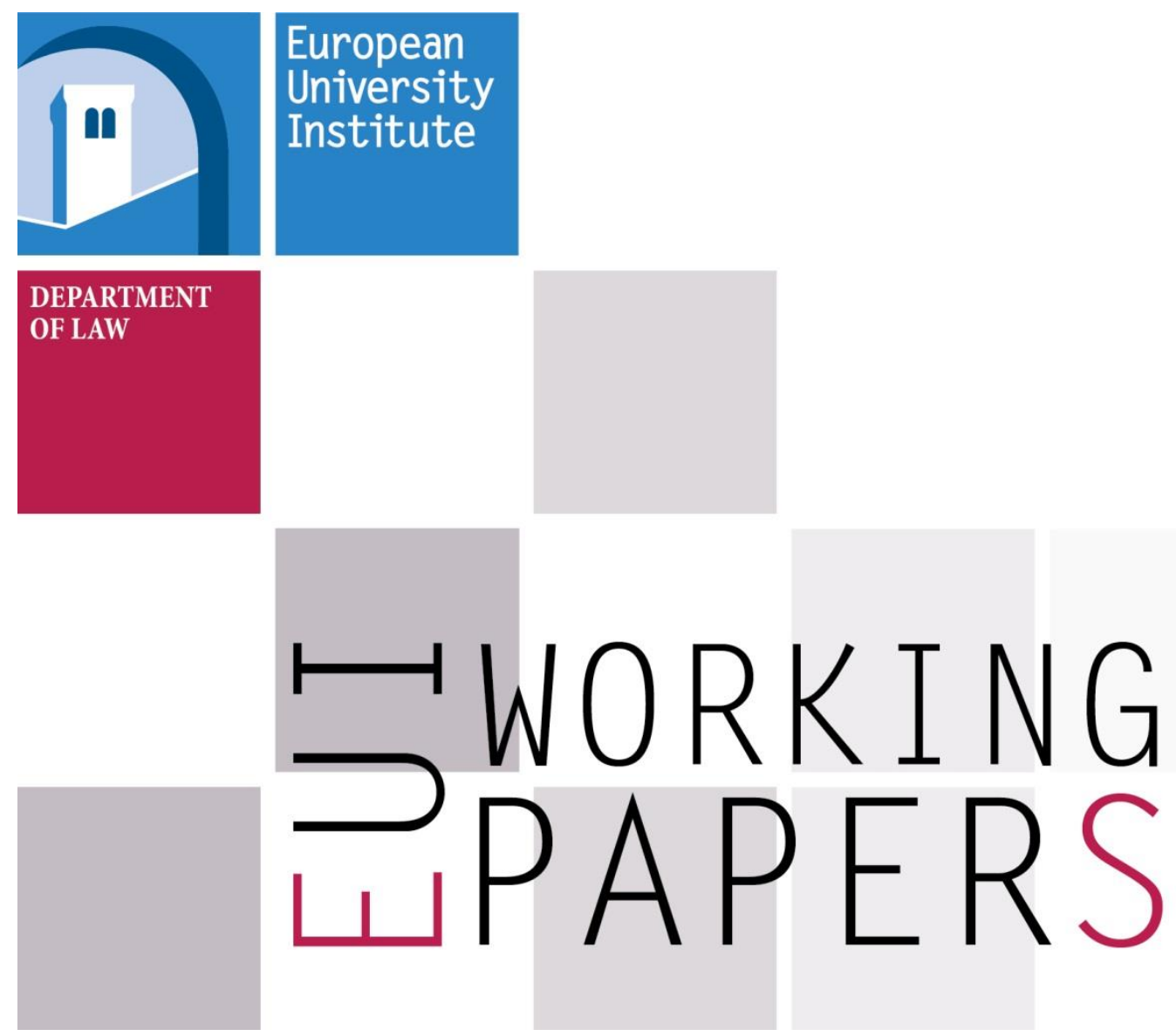

LAW 2021/4

Department of Law

Asymmetric cross-citations in private law:

an empirical study of 28 Supreme Courts in the EU

Sabrina D'Andrea, Nikita Divissenko, Maria Fanou, Anna Krisztián, Jaka Kukavica, Nastazja Potocka-Sionek and Mathias Siems 

European University Institute Department of Law

\section{Asymmetric Cross-Citations in Private LaW: AN EMPIRICAL STUDY OF 28 SUPREME COURTS IN THE EU}

Sabrina D'Andrea, Nikita Divissenko, Maria Fanou, Anna

Krisztián, Jaka Kukavica, Nastazja Potocka-Sionek and Mathias

Siems

EUI Working Paper LAW 2021/4 
This text may be downloaded for personal research purposes only. Any additional reproduction for other purposes, whether in hard copy or electronically, requires the consent of the author(s), editor(s). If cited or quoted, reference should be made to the full name of the author(s), editor(s), the title, the working paper or other series, the year, and the publisher.

ISSN 1725-6739

(C) Author(s), 2021

Printed in Italy

European University Institute

Badia Fiesolana

I-50014 San Domenico di Fiesole (FI)

Italy

www.eui.eu

cadmus.eui.eu 


\begin{abstract}
Recent years have seen a growing volume of research on citations between courts from different countries. This article fills a gap in the current literature by presenting and analysing cross-citations between the highest domestic courts responsible for matters of private law in the EU from 2000 to 2018. It addresses two main questions: first, to what extent do judges cite foreign case law in their decisions? Second, what may explain the varying levels of engagement of supreme courts with foreign case law? Our findings offer a mixed result as to the nature and frequency of such cross-citations. Overall, we identify 2,984 cross-citations; yet, only in few instances do we find a reciprocal relationship between the supreme courts of two countries, while more generally an asymmetric picture emerges. The article also discusses whether problems with the ease of access to court decisions may partly be responsible for limitations in the use of cross-citations.
\end{abstract}

\title{
Keywords
}

Cross-citations, supreme courts in the EU, judicial reasoning, legal families, access to court decisions

\section{Acknowledgement}

We thank Martin Gelter, Urška Šadl, Rebecca Williams, the participants of the Law Faculty Seminar held at the European University Institute on 18 November 2020 and two anonymous reviewers for their helpful comments. We are also grateful for the financial support of the European University Institute which allowed us to collect the empirical data underlying this article. The data will be made available at http://cross-citations.blogspot.com/.

The final version of this paper will be published in the Maastricht Journal of European and Comparative Law (2021) 
Author contact details:

Mathias Siems

Law Department

European University Institute

mathias.siems@eui.eu 


\section{Table of contents}

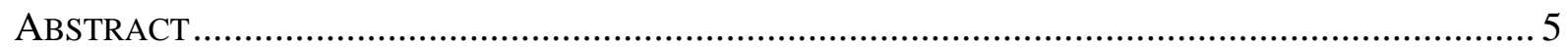

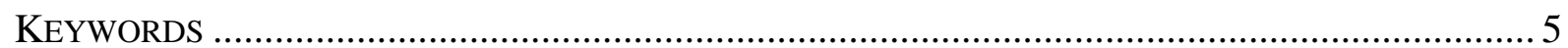

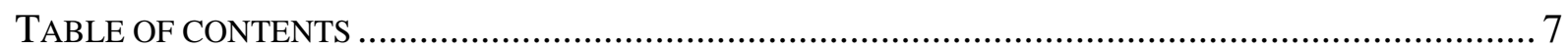

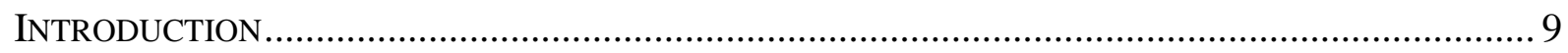

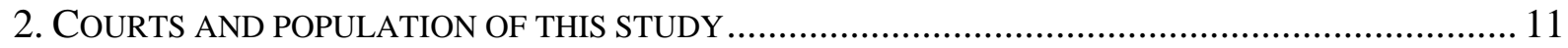

3. TAXONOMY OF COURTS BASED ON FREQUENCY OF CROSS-CITATIONS …............................. 19

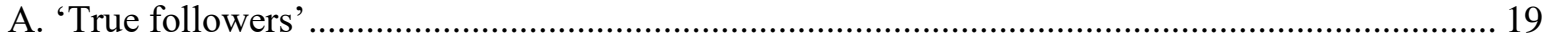

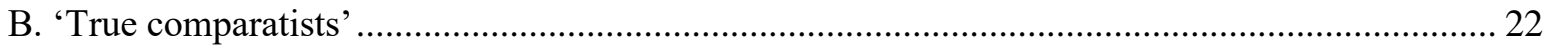

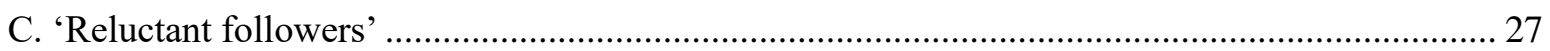

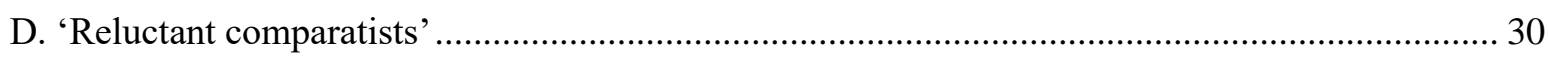

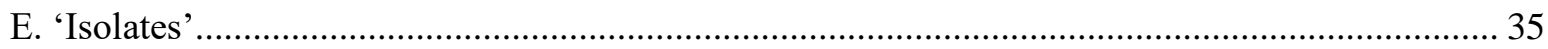

4. TRANSPARENCY AND EASE OF ACCESS TO SUPREME COURT DECISIONS ............................... 38

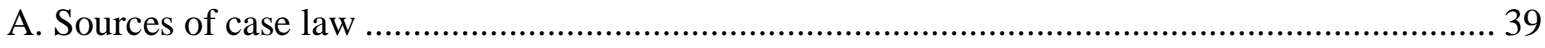

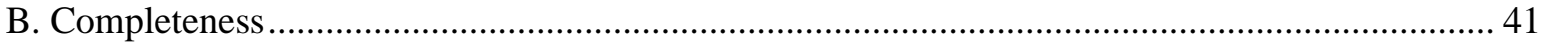

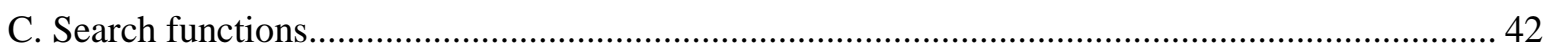

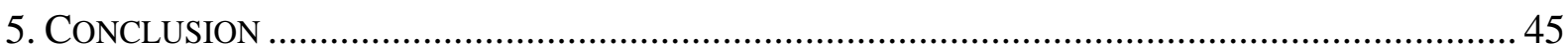





\section{Introduction}

What, if anything, is the relationship between supreme courts of different countries? It could be suggested that this question is rather easy to answer as domestic courts may be perceived as similar to Leibniz's 'monads' - elements of the universe which are fully internally determined and which do not interact with each other. ${ }^{1}$ However, there is also the view that today 'judges see each other not only as servants and representatives of a particular polity, but also as fellow professionals in an endeavour that transcends national borders. ${ }^{2}$ In particular, it may be suggested that national supreme courts of a deeply connected regional community, such as the European Union, should be engaged in forms of judicial dialogue to support regional integration. Indeed, according to prior research, judicial dialogue of this kind has been increasingly more common in Europe in recent years: in England ${ }^{3}$, France, ${ }^{4}$ and most other European jurisdictions, ${ }^{5}$ comparative law has been deemed as the new normal in judicial reasoning. Thus, for example, Andenas and Fairgrieve have argued that '[c]ourts make use of comparative law, and make open reference to it, to an unprecedented extent. ${ }^{6}$

This article fills a gap in the current literature by analysing a particularly visible form of such regional judicial dialogue, namely citations between the highest domestic courts responsible for matters of private law in the EU (from herein: "supreme courts" $)$. The focus on private law courts has been chosen as many other studies have specifically examined judicial dialogue in matters of constitutional law. ${ }^{8}$ For constitutional law, some of this research explores judicial dialogue between courts from different parts of the world (notably the influence of the US Supreme Court). For EU private law, it can be noted that many topics of private law are at the forefront of legislative and non-legislative measures undertaken in order to create a common market, ${ }^{9}$ and it has also been asked how far there may be a

${ }^{1}$ G.W. Leibniz, La Monadologie (Librairie Delagrave 1978, original from 1714).

2 A.-M. Slaughter, ‘A Global Community of Courts', 44 Harvard International Law Journal (2003), p. 191, 193.

${ }^{3}$ Lord Bingham, 'There Is a World Elsewhere: The Changing Perspectives of English Law', 41 International and Comparative Law Quarterly (1992), p. 513; Lord Justice Mance, 'Foreign and Comparative Law in the Courts Teaching and Practicing Law in the 21st Century: A Symposium Honoring the Distinguished Career of Professor Hans Baade', 36 Texas International Law Journal (2001), p. 415.

${ }^{4}$ M. Andenas and D. Fairgrieve, 'Introduction: Finding a Common Language for Open Legal Systems', in G. Canivet, M. Andenas and D. Fairgrieve (eds.), Comparative Law Before the Courts (British Institute of International and Comparative Law 2004), p. xxxi.

${ }^{5}$ Ibid at p. xxx-xxxi.

${ }^{6}$ M. Andenas and D. Fairgrieve, “"There Is A World Elsewhere” - Lord Bingham and Comparative Law', in M. Andenas and D. Fairgrieve (eds.), Tom Bingham and the Transformation of the Law: A Liber Amicorum (Oxford University Press 2009), p. 840 .

${ }^{7}$ This includes general supreme courts with competences to decide on other matters (but not constitutional courts). See Table 1 in section 2, below, for the list of courts included in this study.

${ }^{8}$ E.g., F. Ferrari (ed.), Judicial Cosmopolitanism: The Use of Foreign Law in Contemporary Constitutional Systems (Brill Nijhoff 2019); A. Müller (ed.), Judicial Dialogue and Human Rights (Cambridge University Press 2017); T. Groppi and M.-C. Ponthoreau (eds.), The Use of Foreign Precedents by Constitutional Judges (Hart 2013).

${ }^{9}$ While a European Civil Code is unlikely to emerge in the near future, EU measures in private law feature under a variety of headings, such as consumer law (https://ec.europa.eu/info/law/law-topic/consumers_en), doing business in the EU (https://ec.europa.eu/info/business-economy-euro/doing-business-eu_en) and civil justice (https://ec.europa.eu/info/policies/justice-and-fundamental-rights/civil-justice_en). 
'transformative role of judges as regards rules of private law in Europe' ${ }^{10}$ As far as empirical research is concerned, prior projects have examined courts of the EU judicial system from an empirical perspective, ${ }^{11}$ while projects on judicial dialogue have conducted quantitative and qualitative research on a selected number of supreme courts. ${ }^{12}$

This article, and its underlying project, examines cross-citations between all of the supreme courts of the EU Member States from 2000 to 2018. Specifically, it addresses two main questions: first, to what extent do these judges cite foreign case law in their decisions? Second, what may explain the varying levels of engagement of supreme courts with foreign case law? Citations between these courts (from herein: 'cross-citations') form the basis of analysis in this article, as they present a visible sign of the influence of foreign courts on a particular court. Having identified 2,984 of such cross-citations, this article will also discuss how the judicial style of some courts causes a reluctance to provide detailed explanations of the court's reasoning. In addition, it will suggest that problems with the ease of access to court decisions may partly be responsible for the limited use of cross-citations. Thus, this article will show that there is some evidence of cross-citations between supreme courts in the EU. However, this occurs in rather asymmetric and heterogenic patterns.

This article is part of a wider project that will analyse further details of these 2,984 cross-citations. For example, while this article discusses the total number of cross-citations per court, future papers will explore possible variations across time and areas of law. Methodologically, these future papers will make use of econometric methods and network analysis. Thus, these papers will use the data on crosscitations in an instrumental way in order to empirically test certain hypotheses. By contrast, this article is interested in the variations of cross-citations of each of the courts on their own terms. Given the aim of this article to map the cross-citations between the 28 courts at a general level, it is acknowledged, but not considered in detail, that there may also be idiosyncratic reasons that can account for specific cross-citations, be it related to a particular judge (e.g., language skills, foreign legal education, involvement in judicial networks), a particular case (e.g., lawyers referring to foreign precedents, the prominence or content of a particular foreign judgment) or the infrastructure of a particular court (e.g., having access to a library or database with foreign judgments or research assistants).

The structure of this article is as follows. Section 2 outlines the courts and population of this study. This section also introduces a classification of supreme courts by cross-citations, distinguishing between 'true followers', 'true comparatists', 'reluctant followers', 'reluctant comparatists' and 'isolates'. Section 3 then explains in detail how groups of supreme courts show fundamentally different crosscitations patterns, with some of them rarely citing any foreign court, others citing mainly one foreign court, and some also showing evidence of relatively frequent comparative reasoning. It also provides explanations of these differences, for example, discussing the role of legal families for cross-citations. Moreover, identifying these citation patterns provides insights into the transparency and ease of access of supreme-court decisions. These points are discussed in Section 4, which also explains the data collection process that formed the basis of this project. Section 5 concludes by re-visiting the asymmetric citation patterns identified in this article.

${ }^{10}$ L. Burgers, J. Van Duin and C. Mak, 'Judges in Utopia The Transformative Role of the Judiciary in European Private Law', 28 European Review of Private Law (2020), p. 865, 883. For the underlying project see also 'Judges in Utopia: The new constructive approach to the social justice debate in European private law', https://www.nwo.nl/en/projects/452-13-009.

11 See e.g. the projects 'EUTHORITY: Conflict and cooperation in the European Union legal system', https://www.law.kuleuven.be/euthority/EN; 'EUCLCORP: EU Case Law Corpus Project ' https://llecj.karenmcauliffe.com/euclcorp/; and 'The Coding Project', https://noleslaw.net/the-coding-project/.

${ }^{12}$ See e.g. M. Gelter and M. Siems, 'Citations to Foreign Courts - Illegitimate and Superfluous, or Unavoidable? Evidence from Europe', 62 American Journal of Comparative Law (2014), p. 35 (quantitative analysis of ten European courts); M. Bobek, Comparative Reasoning in European Supreme Courts (Oxford University Press 2013) (with empirical information about five courts); E. Mak, Judicial Decision-Making in a Globalised World (Hart 2013) (based on qualitative empirical work in three countries). See also M. Andenas and D. Fairgrieve (eds.), Courts and Comparative Law (Oxford University Press 2015) (collection of papers on a variety of topics). 


\section{Courts and population of this study}

The present study encompasses case law of the supreme courts responsible for matters of private law in 28 EU Member States (still including the United Kingdom as we analyse data prior to its departure from the EU). Table 1, below, presents the data on supreme courts used in this article. In the first six columns, the table displays the complete list of countries and courts as well as the databases used in this study including some further information (URLs, originator, need for subscription). Details on these databases will be discussed later in this article (in the context of the transparency and ease of access of supremecourt decisions). ${ }^{13}$ Finally, in the remaining four columns, the table shows the total number of decisions, the number of citations made to the other 27 courts per each court, the number of citations per 1000 decisions and the most frequently cited court within each jurisdiction.

The population of this study is the total number of available decisions of the supreme courts in private law matters throughout the period from 2000 to 2018 as displayed in Table 1. We compared the collected data with the information on the number of supreme court decisions available in the database of the European Commission for the Efficiency of Justice (CEPEJ) ${ }^{14}$ in order to check the completeness of our data, while also detecting a number of inconsistencies of the CEPEJ data (and thus confirming the criticism of the CEPEJ database by other researchers). ${ }^{15}$ In some instances, it was necessary to estimate the total number of decisions, as the database did not report the total number of decisions or it did not separate the number of civil and criminal cases (thus we used an estimate of private law cases). ${ }^{16}$

\footnotetext{
${ }^{13}$ See section 4, below.

${ }^{14}$ See https://www.coe.int/en/web/cepej/country-profiles.

${ }^{15}$ M. Fabri, 'Methodological Issues in the Comparative Analysis of the Number of Judges, Administrative Personnel, and Court Performance Collected by the Commission for the Efficiency of Justice of the Council of Europe', 7 Oñati SocioLegal Series (2017), p. 635; M. Fabri, 'Comparing the Number of Judges and Court Staff across European Countries', 26 International Journal of the Legal Profession (2019), p. 14.

${ }^{16}$ Specifically, this was necessary for France in the former case and for Austria, Ireland, Sweden and the UK in the latter one; see also Table 1 as well as section 4.C, below.
} 
Table 1. Data on supreme courts of this study (all referring to the years 2000 to 2018)

\begin{tabular}{|c|c|c|c|c|c|c|c|c|c|}
\hline Country & Name of the court & Database(s) & Database URL & $\begin{array}{l}\text { Originator } \\
\text { of database }\end{array}$ & $\begin{array}{l}\text { Need for } \\
\text { subscrip } \\
\text { tion }\end{array}$ & $\begin{array}{l}\text { Total } \\
\text { number } \\
\text { of } \\
\text { decisions }\end{array}$ & $\begin{array}{l}\text { Total } \\
\text { number } \\
\text { of cross- } \\
\text { citations }\end{array}$ & $\begin{array}{l}\text { Cross- } \\
\text { citations per } \\
1000 \\
\text { decisions }\end{array}$ & $\begin{array}{l}\text { Most frequently } \\
\text { cited foreign } \\
\text { supreme court }\end{array}$ \\
\hline Austria & $\begin{array}{l}\text { Oberster } \\
\text { Gerichtshof }\end{array}$ & $\begin{array}{l}\text { Rechtsinforma } \\
\text { tionssystem } \\
\text { des Bundes } \\
\text { (RIS) }\end{array}$ & $\begin{array}{l}\text { http://www.ris.bka.gv. } \\
\text { at/ }\end{array}$ & Public & No & $\sim 17,621$ & 1,068 & 59.25 & Germany $(1,044)$ \\
\hline Belgium & $\begin{array}{l}\text { Cour de cassation, } \\
\text { Hof van Cassatie }\end{array}$ & Juridat & $\begin{array}{l}\text { http://jure.juridat.just.f } \\
\text { gov.be/JuridatSearchC } \\
\text { ombined/ }\end{array}$ & Public & No & 24,754 & 88 & 3.6 & France (71) \\
\hline Bulgaria & $\begin{array}{l}\text { Върховен } \\
\text { касационен съд }\end{array}$ & Lakorda & http://web.lakorda.com & $\begin{array}{l}\text { Private, } \\
\text { commercial }\end{array}$ & Yes & 40,176 & 0 & 0 & N/A \\
\hline Croatia & Vrhovni sud & Sudska praksa & $\begin{array}{l}\text { https://sudskapraksa.cs } \\
\text { p.vsrh.hr/ }\end{array}$ & Public & No & 92,919 & 2 & 0.02 & $\begin{array}{l}\text { Austria(1) } \\
\text { Hungary (1) }\end{array}$ \\
\hline Cyprus & 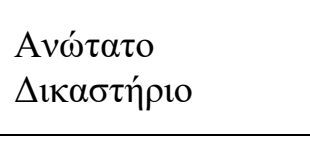 & Cylaw & http://www.cylaw.org/ & $\begin{array}{l}\text { Private, } \\
\text { non- } \\
\text { commercial }\end{array}$ & No & 7,654 & 229 & 29.14 & UK (223) \\
\hline $\begin{array}{l}\text { Czech } \\
\text { Republic }\end{array}$ & Nejvyšší soud & Nejvyšší soud & $\begin{array}{l}\text { http://www.nsoud.cz/J } \\
\text { udikatura/ns_web.nsf/ } \\
\text { WebSpreadSearch }\end{array}$ & Public & No & 84,293 & 56 & 0.64 & Slovakia (37) \\
\hline Denmark & Højesteret & Højesteret & $\begin{array}{l}\text { https://domstol.dk/hoej } \\
\text { esteret/afgoerelsesdata } \\
\text { base/ }\end{array}$ & Public & No & $1,660^{17}$ & 14 & 4.22 & $\begin{array}{l}\text { Germany (3) } \\
\text { Sweden (3) }\end{array}$ \\
\hline
\end{tabular}

${ }^{17}$ Only cases from 2009 onward were available at the time of writing. 
Asymmetric Cross-Citations in Private Law: An Empirical Study of 28 Supreme Courts in the EU

\begin{tabular}{|c|c|c|c|c|c|c|c|c|c|}
\hline & & & & & & & & & Netherlands (3) \\
\hline Estonia & Riigikohus & Riigikohus & $\begin{array}{l}\text { https://www.riigikohus } \\
\text {.ee/et/lahendid? }\end{array}$ & Public & No & 3,183 & 3 & 0.94 & Germany (2) \\
\hline Finland & korkein oikeus & Edilex & $\begin{array}{l}\text { https://www.edilex.fi/k } \\
\text { ko }\end{array}$ & $\begin{array}{l}\text { Private, } \\
\text { commercial }\end{array}$ & No & 1,382 & 2 & 1.45 & $\begin{array}{l}\text { UK (1) } \\
\text { Germany (1) }\end{array}$ \\
\hline \multirow{2}{*}{ France } & \multirow{2}{*}{ Cour de cassation } & LegiFrance & $\begin{array}{l}\text { http://www.legifrance. } \\
\text { gouv.fr }\end{array}$ & Public & No & \multirow[t]{2}{*}{$\sim 176,000$} & \multirow[t]{2}{*}{4718} & \multirow[t]{2}{*}{0.27} & \multirow[t]{2}{*}{ Germany (11) } \\
\hline & & $\begin{array}{ll}\text { Cour de } & \text { de } \\
\text { Cassation } & \\
\end{array}$ & $\begin{array}{l}\text { http://www.courdecass } \\
\text { ation.fr/ }\end{array}$ & Public & No & & & & \\
\hline Germany & $\begin{array}{l}\text { Bundesgerichts- } \\
\text { hof }\end{array}$ & $\begin{array}{l}\text { Entscheidungs } \\
\text { datenbank des } \\
\text { Bundesgericht } \\
\text { shofs }\end{array}$ & $\begin{array}{l}\text { https://juris.bundesgeri } \\
\text { chtshof.de/cgi- } \\
\text { bin/rechtsprechung/list } \\
\text {.py?Gericht=bgh }\end{array}$ & Public & No & 32,997 & 169 & 5.1 & Austria (104) \\
\hline \multirow{2}{*}{ Greece } & \multirow{2}{*}{ 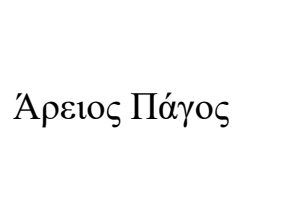 } & Areios Pagos & $\begin{array}{l}\text { http://www.areiospago } \\
\text { s.gr/ }\end{array}$ & Public & No & \multirow[t]{2}{*}{$34,891^{19}$} & \multirow[t]{2}{*}{5} & \multirow[t]{2}{*}{0.14} & \multirow{2}{*}{ Germany (4) } \\
\hline & & Nomos & $\begin{array}{l}\text { https://lawdb.intrasoftn } \\
\text { et.com/ }\end{array}$ & $\begin{array}{l}\text { Private, } \\
\text { commercial }\end{array}$ & Yes & & & & \\
\hline
\end{tabular}

${ }^{18}$ Including advocate general opinions.

${ }^{19}$ Only cases from 2006 onward were available at the time of writing. 


\begin{tabular}{|c|c|c|c|c|c|c|c|c|c|}
\hline & & DSA Isokratis & $\begin{array}{l}\text { http://www.dsanet.gr/1 } \\
\text { 024x768.htm }\end{array}$ & $\begin{array}{l}\text { Private, } \\
\text { non- } \\
\text { commercial }\end{array}$ & $\begin{array}{l}\text { Free for } \\
\text { member } \\
\mathrm{s} \text { of the } \\
\text { Bar only }\end{array}$ & & & & \\
\hline Hungary & $\begin{array}{l}\text { Kúria (since 2012; } \\
\text { prev.: } \\
\text { Magyarország } \\
\text { Legfelsőbb } \\
\text { Bírósága) }\end{array}$ & $\begin{array}{l}\text { Bírósági } \\
\text { Határozatok } \\
\text { Gyüjteménye }\end{array}$ & $\begin{array}{l}\text { https://birosag.hu/biros } \\
\text { agi-hatarozatok- } \\
\text { gyujtemenye }\end{array}$ & Public & No & $35,498^{20}$ & 2 & 0.06 & $\begin{array}{l}\text { Austria (1) } \\
\text { Germany (1) }\end{array}$ \\
\hline Ireland & Supreme Court & BAILII & $\begin{array}{l}\text { https://www.bailii.org/ } \\
\text { ie/cases/IESC/ }\end{array}$ & $\begin{array}{l}\text { Private, } \\
\text { non- } \\
\text { commercial }\end{array}$ & No & $\sim 686$ & 194 & 282.80 & UK $(\sim 192)^{21}$ \\
\hline Italy & $\begin{array}{l}\text { Corte Suprema di } \\
\text { Cassazione }\end{array}$ & Dejure & http://dejure.giuffre.it/ & $\begin{array}{l}\text { Private, } \\
\text { commercial }\end{array}$ & Yes & 445,709 & 85 & 0.19 & France (37) \\
\hline Latvia & Augstākā tiesa & Augstākā tiesa & $\begin{array}{l}\text { https://manas.tiesas.lv/ } \\
\text { eTiesasMvc/nolemumi }\end{array}$ & Public & No & 3,054 & 0 & 0 & N/A \\
\hline Lithuania & $\begin{array}{l}\text { Aukščiausiasis } \\
\text { Teismas }\end{array}$ & Liteko & $\begin{array}{l}\text { http://liteko.teismai.lt/ } \\
\text { viesasprendimupaieska } \\
\text { /detalipaieska.aspx?det } \\
\text { ali=2 }\end{array}$ & Public & No & 7,925 & 11 & 1.39 & Germany (5) \\
\hline $\begin{array}{l}\text { Luxembo } \\
\text { urg }\end{array}$ & Cour de Cassation & $\begin{array}{l}\text { Cour de } \\
\text { Cassation } \\
\text { (justice.public. } \\
\text { lu) }\end{array}$ & $\begin{array}{l}\text { https://justice.public.lu } \\
\text { /fr/jurisprudence/cour- } \\
\text { cassation.html }\end{array}$ & Public & No & $1,876^{22}$ & 57 & 33.58 & France (45) \\
\hline
\end{tabular}

\footnotetext{
${ }^{20}$ The database covers the whole period, however the number of judgments available for 2000 to 2008 is low and thus likely to be selective.

${ }^{21}$ For the estimation of the UK citations see section 4.C, below.

${ }^{22}$ Cases for 2000 and 2001 were not available at the time of writing.
} 
Asymmetric Cross-Citations in Private Law: An Empirical Study of 28 Supreme Courts in the EU

\begin{tabular}{|c|c|c|c|c|c|c|c|c|c|}
\hline Malta & Court of Appeal & eCourts & $\begin{array}{l}\text { https://ecourts.gov.mt/ } \\
\text { onlineservices/Judgem } \\
\text { ents }\end{array}$ & Public & No & 9,57723 & 299 & 31.22 & $\mathrm{UK}(\sim 143)^{24}$ \\
\hline $\begin{array}{l}\text { Netherlan } \\
d s\end{array}$ & Hoge Raad & de Rechtspraak & $\begin{array}{l}\text { https://uitspraken.recht } \\
\text { spraak.nl/ }\end{array}$ & Public & No & 18,884 & $221^{25}$ & 11.70 & Germany (114) \\
\hline \multirow{2}{*}{ Poland } & \multirow{2}{*}{ Sąd Najwyższy } & $\begin{array}{l}\text { Sąd } \\
\text { Najwyższy }\end{array}$ & $\begin{array}{l}\text { http://www.sn.pl/orzec } \\
\text { znictwo/SitePages/ } \\
\text { Baza_orzeczen.aspx }\end{array}$ & Public & No & \multirow{2}{*}{$42,983^{26}$} & \multirow{2}{*}{24} & \multirow{2}{*}{0.56} & \multirow{2}{*}{ Germany (9) } \\
\hline & & LEX & http://sip.lex.pl & $\begin{array}{l}\text { Private, } \\
\text { commercial }\end{array}$ & Yes & & & & \\
\hline Portugal & $\begin{array}{l}\text { Supremo Tribunal } \\
\text { de Justiça }\end{array}$ & IGFEJ & http://www.dgsi.pt & Public & No & 48,513 & 42 & 0.87 & France (15) \\
\hline Romania & $\begin{array}{l}\text { Înalta Curte de } \\
\text { Casație și Justiție }\end{array}$ & $\begin{array}{l}\text { Inalta Curte de } \\
\text { Casaţie şi } \\
\text { Justiţie }\end{array}$ & $\begin{array}{l}\text { http://www.scj.ro/en/7 } \\
\text { 36/Search- } \\
\text { jurisprudence }\end{array}$ & Public & No & $60,792^{27}$ & 5 & 0.08 & Germany (3) \\
\hline
\end{tabular}

${ }^{23}$ Cases for 2000 were not available at the time of writing.

${ }^{24}$ For the estimation of the UK citations see section 4.C, below.

${ }^{25}$ Including advocate general opinions.

${ }^{26}$ Full time period is available at the website, although the number of cases available in the official database in the early 2000 s is relatively low.

${ }^{27}$ Cases from 2000-2001 were not available at the time of writing. 


\begin{tabular}{|l|l|l|l|l|l|l|l|l|}
\hline Slovakia & Najvyšší súd & Najvyšší súd & $\begin{array}{l}\text { https://www.nsud.sk/r } \\
\text { ozhodnutia }\end{array}$ & Public & No & 37,917 & 20728 & 5.46 \\
\hline Slovenia & Vrhovno sodišče & Sodna praksa & $\begin{array}{l}\text { http://www.sodnapraks } \\
\text { a.si// }\end{array}$ & Public & No & 37,899 & 63 & 1.66 \\
\hline Spain & Tribunal Supremo & CENDOJ & $\begin{array}{l}\text { http://www.poderjudic } \\
\text { ial.es/search/ }\end{array}$ & Public & No & 96,392 & 16 & Republic \\
\hline Sweden & Högsta domstolen & Lagrummet & $\begin{array}{l}\text { http://rattsinfosok.dom } \\
\text { stol.se/lagrummet }\end{array}$ & Public & No & $\sim 1,990$ & 16 & 8.17 \\
\hline UK & $\begin{array}{l}\text { Supreme Court } \\
\text { (since 2009; prev.: } \\
\text { House of Lords) }\end{array}$ & BAILII & $\begin{array}{l}\text { https://www.bailii.org/uk/c } \\
\text { ases/UKHL/ } \\
\text { https://www.bailii.org/uk/c } \\
\text { ases/UKsc/ }\end{array}$ & $\begin{array}{l}\text { Private, } \\
\text { non- } \\
\text { commercial }\end{array}$ & No & $\sim 607$ & France (5) \\
\hline
\end{tabular}

\footnotetext{
${ }^{28}$ Full time period is available at the website, although the number of cases published before 2008 is scarce. Blank search for the time period from 01.01 .2000 to 31.12 .2006 shows 36 results, out
} of which only 7 are civil law cases. 
The total number of cross-citations identified in this study is $2,984^{29}$ For many of the courts, the yearly rate of cross-citations is low (cf. Table 1: only seven countries have more than one hundred crosscitations overall). Thus, this article analyses the aggregate of these citations in the entire time period (2000 to 2018). The start date of the year 2000 was chosen since, in many countries, earlier decisions would not be accessible with the relevant databases. ${ }^{30}$

For Belgium, France and the Netherlands ${ }^{31}$ we also included cross-citations in the opinions of advocates general. These opinions do not have a binding force. Yet, their inclusion was necessary because the legal justification for a decision appears only in the opinions of the advocates general, which contrasts with other countries where legal justification is found in the decision itself. Thus, they can be seen as functionally equivalent to the more elaborate judgments found in other countries. ${ }^{32}$

In all cases, we checked the citations by hand in order to exclude false positives. ${ }^{33}$ This also included checking whether citations concerned topics of 'private law', understood widely, for example, including topics of commercial law and tort/state liability law even though they may overlap with topics of public law in some circumstances (or in some jurisdictions). ${ }^{34}$ Otherwise, we maintained a broad approach when identifying cross-citations. For instance, broad references to foreign supreme court jurisprudence made by the judges in the resolution of the decision have been counted as cross-citations if the name of the foreign court was mentioned (e.g. in a phrase such as 'according to the case law of the BGH' but not merely 'according to German case law'). We also included all citations regardless of their possible motivations; thus, some of the cross-citations may be due to the fact that the court was genuinely interested in the foreign court's reasoning while others may be of a more 'ornamental nature'. ${ }^{35}$

${ }^{29}$ This counts each decision that cites one of the other 27 courts. If the same decision cites two or more foreign courts, each of these cross-citations was considered (while we did not consider multiple citations to the same court in the same decision as separate citations).

${ }^{30}$ For details see section 4.B., below.

${ }^{31}$ In Luxembourg too, the court has advocates general; yet, it was impossible to get access to their opinions; see section 4.B, below.

${ }^{32}$ Following M. Gelter and M. Siems, 62 American Journal of Comparative Law (2014), p. 45-6.

${ }^{33}$ For example, where a particular abbreviation may be ambiguous (e.g., the German supreme court typically cites the Austrian supreme court as 'OGH'; yet, 'OGH' can also refer to another court, the 'Oberster Gerichtshof für die Britische Zone' that existed in the British occupation zone of Germany between 1948 and 1950).

${ }^{34}$ E.g., this reflects that rules of securities law may allow both private and public enforcement; questions of state liability law may be addressed by tools of private law in some jurisdictions; it is also possible that questions of human rights are relevant in private law cases.

${ }^{35}$ For different purposes of citing foreign case law see also M. Gelter and M. Siems, 62 American Journal of Comparative Law (2014), p. 69-82; H. Tyrrell, Human Rights in the UK and the Influence of Foreign Jurisprudence (Hart 2018) p. 5473. 


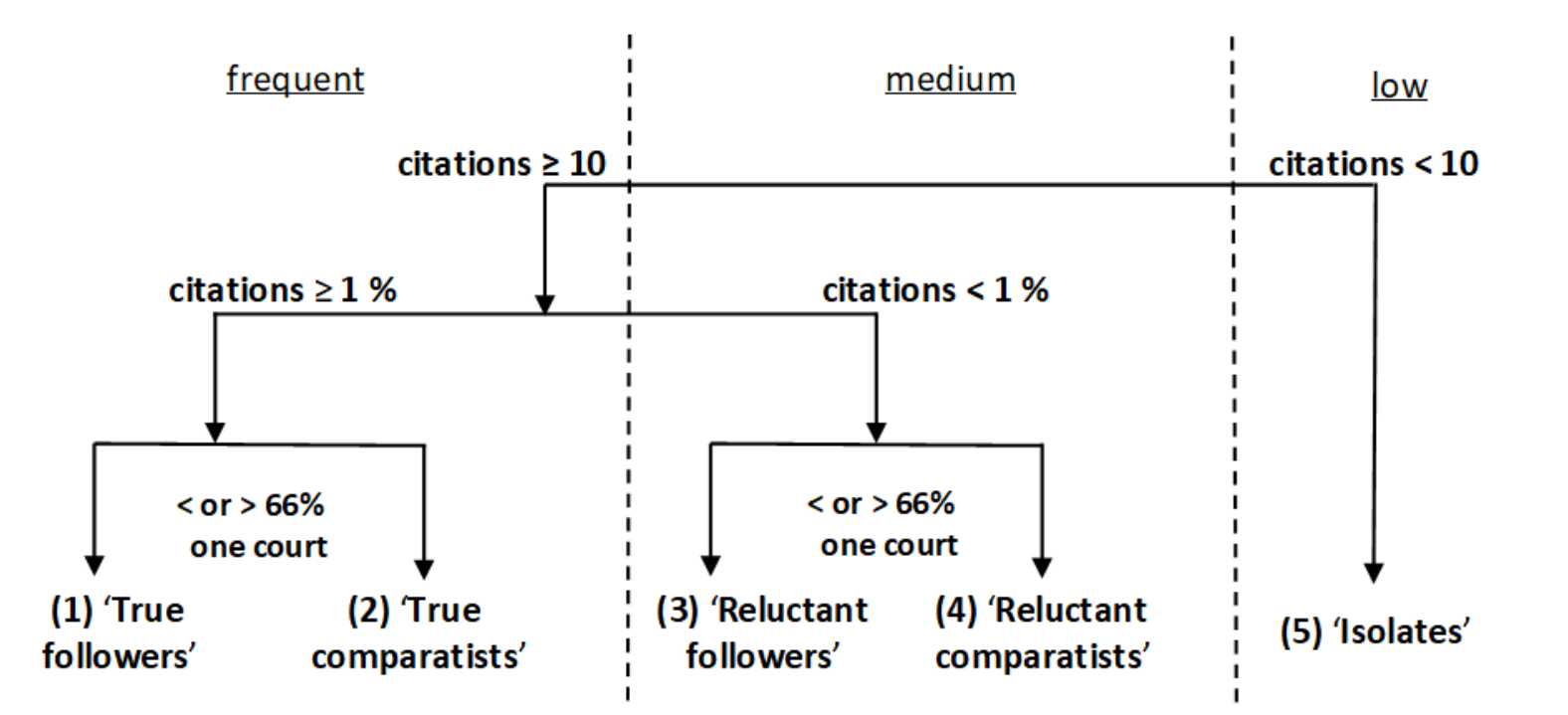

Figure 1. Classification of highest courts by cross-citations

The cross-citation data obtained in this study can be presented in both absolute and relative numbers. In principle, it may seem more plausible to rely on the number of citations relative to the total number of decisions of a particular court. Thus, the argument would be that the frequency of foreign citations of a particular court should not be disadvantaged due to the fact that it only decided a small number of cases. This being said, it is also not clear whether the number of foreign citations is really affected by the total number of decisions of a particular court. One might suspect that courts will only undertake the effort to research foreign case law in non-routine cases, in which there will be an appeal to the respective supreme court in every country. In other words, the relative number may not provide significant insights into patterns of judicial dialogue, as variations in the total number of decisions are mainly driven by other factors. These include the fact that some high courts write many very short decisions (which are unlikely to cite any foreign courts), while in other countries such cases would not even be decided by the supreme court. ${ }^{36}$

Thus, for the purposes of this study, we use both the absolute and the relative citation data in order to categorise the courts into five groups. The categories are presented graphically in Figure 1 and, while the specific thresholds have a degree of subjectivity, the analysis in the subsequent section of this article will show that at least four of these categories point towards a common set of explanations. ${ }^{37}$ In detail, firstly, based on the absolute number of citations, we distinguish the courts with less than ten citations in the studied period (called 'isolates', (5)) from those with ten or more citations. The latter group of courts is further subdivided in two, where the distinction is made between 'frequent' and 'medium' comparatists based on the relative data points. The frequent comparatists are courts that cite foreign courts in more than 10 out of 1000 (i.e. in more than 1\%) of cases, whereas medium comparatists do not reach this threshold. The two groups are then split into four categories based on further variations of the cited courts. Thus, amongst frequently-citing courts those citing primarily one of the other supreme court (more than $66 \%$ of its citations) constitute the category of 'true followers' (1). Supreme courts citing a variety of foreign courts (less than $66 \%$ of its citations to one court) constitute the category of 'true comparatists' (2) - thus, this category is comprised of courts with a relatively high number of citations but no single predominantly cited court. Medium comparatists are divided in two further categories following the same principle - 'reluctant followers' (3), which include courts which primarily

\footnotetext{
${ }^{36}$ Similarly, M. Gelter and M. Siems, 'Networks, Dialogue or One-Way Traffic? An Empirical Analysis of Cross-Citations between Ten of Europe's Highest Courts', 8 Utrecht Law Review (2012), p. 88, 91-4.

${ }^{37}$ The possible exception is the section 3.D, below.
} 
cite only one foreign court. By comparison 'reluctant comparatists' (4) cite a wider variety of foreign courts, though they do so less frequently than true comparatists.

\section{Taxonomy of courts based on frequency of cross-citations}

The taxonomy of this section builds on the five categories presented in Figure 1. It also provides possible explanations as to why particular countries may fall under a particular category. Legal families in particular may sometimes explain why certain courts cite each other and they may also be a determinant for the argumentative style of judgments (and thus the likelihood to refer to foreign case law). In addition, we consider other factors such as a common language between countries, a shared history and the relationship between larger and smaller jurisdictions. Discussing these explanations, it is clear that many of them are not independent of each other: for example, countries that share a common history and language are often (but not always) part of the same legal family. In addition, we will see that it is necessary to examine each of the 28 courts in some detail in order to discern how these reasons play out for each of them.

\section{A. 'True followers'}

The first category of foreign supreme court citations refers to the category of 'true followers'. As noted above, these countries fulfil three criteria. First, in all of their judgments delivered in the examined time period, they cited foreign supreme courts at least ten times (absolute number). Second, these citations made up at least one percent of the total number of judgments delivered (relative number). Third, more than $66 \%$ of the citations referred to a single foreign supreme court, ${ }^{38}$ i.e. these countries closely follow the jurisprudence of one particular foreign supreme court. In the present case, these countries are Austria, Cyprus, Ireland and Luxembourg. As shown in Figure 2, the Austrian Supreme Court cited most frequently the German Supreme Court (1,044 out of 1,068 citations). For the supreme courts of Cyprus and Ireland, it was the Supreme Court of the United Kingdom (223 out of 229 citations for Cyprus and 192 out of 194 citations for Ireland), whereas the Luxembourg court referred to the French court the most regularly (45 out of 57 citations).

\footnotetext{
${ }^{38}$ Compare with 'true comparatists' (section 3.B, below) which tend to cite a number of different foreign courts as opposed to the concentration of citations to one foreign court in the case of the 'true followers'.
} 
200

150

100

50

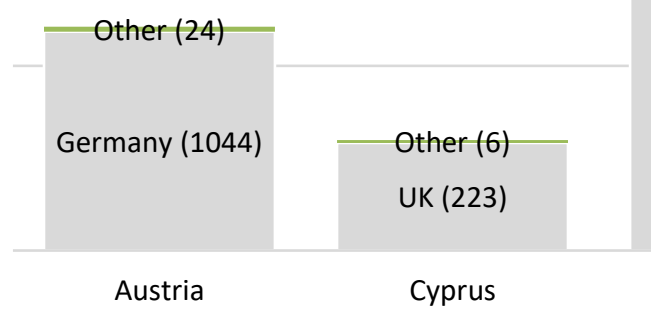

UK (192)

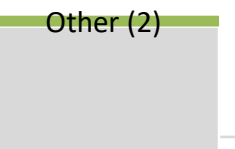

Explanatory note: the scale of the chart refers to the relative frequency of cross-citations while the numbers indicated in brackets in each column refers to absolute numbers of cross-citations of each court

\section{Figure 2. Cross-citations of the supreme courts of Austria, Cyprus, Ireland and Luxembourg}

Already at a first glance there seems to exist a plausible explanation to this finding. All four 'true followers' are relatively small jurisdictions with historic ties to neighbouring larger jurisdictions whose legal developments they may traditionally have reasons to follow. This does not mean that amongst these countries the level of the foreign influence is identical. In particular, the information about the relative frequency in Figure 2 shows that the attachment of Ireland to the UK far exceeds those of the other three countries (in line with prior research identifying a high degree of such influence in the case law of the Irish Supreme Court ${ }^{39}$ ).

For each of the four countries, the following more specific explanations can be added: German legal thinking is known to have had a strong influence on many legal systems in Central and Eastern Europe, including Austria. ${ }^{40}$ While the Austrian Civil Code (ABGB) predates the German Civil Code (BGB),

\footnotetext{
${ }^{39}$ E. Carolan, 'The Supreme Court of Ireland', in A. Jakab, A. Dyevre and G. Itzcovich (eds.), Comparative Constitutional Reasoning (Cambridge University Press 2017) p. 438, 458 (in sample of 40 cases, finding that 31 refer to foreign sources with the further statement that 'English authorities dominate to a considerable degree').

${ }^{40}$ For the German influence in Central and Eastern Europe see also sections 3.D and 3.E, below.
} 
nowadays the interpretation of the ABGB is often inspired by the interpretation of the BGB, similarly to other areas of private law. ${ }^{41}$ Our observation that the Austrian supreme court (Oberster Gerichtshof) mostly cites the German court comes as no surprise in light of this. By comparison, citations to other foreign courts are significantly less frequent: Italy ( 9 citations), France, ( 7 citations), the Netherlands (3 citations), the UK (3 citations), Ireland (1 citations) and Luxembourg (1 citations).

The Cypriot legal system, often referred to as a mixed system, retains essential elements of the English common law system, due to the UK's relatively recent foreign rule in Cyprus which ended only in 1960. To give an example, while Cyprus does not use the jury system for civil or criminal trials, it applies the principle of stare decisis as a result of its common law origins. ${ }^{42}$ However, as the Cypriot legal system is mixed, it is also influenced by further legal traditions. According to Symeonides, the two main areas of law where Cyprus has typically drawn from non-English sources (i.e. Greek, French, and more traditionally Roman-Byzantine and Ottoman law) are administrative law and constitutional law. ${ }^{43}$ This explains our findings regarding significant private law references by the Cypriot supreme court

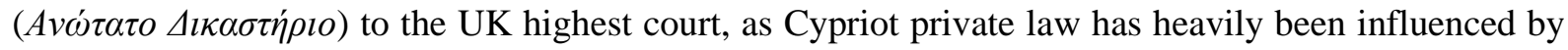
common law. ${ }^{44}$ By comparison, the Greek influence is modest in this regard with just 5 of the remaining cross-citations.

Ireland acquired independence from the United Kingdom in 1922, inheriting its common law system though showing some variations to it. ${ }^{45}$ For example, Ireland's written constitution is something the UK still lacks. Upon achieving independence, Ireland adopted the bulk of the pre-existing body of British law, subjecting it to review against the standards of the Irish Constitution. ${ }^{46}$ In this sense, pre-1922 British case law still forms part of the Irish legal system. The Irish Supreme Court often refers to these older pre-independence precedents as well as more modern UK cases, in particular in matters of private law. ${ }^{47}$ Given this close historic relationship of the two legal systems, it comes as no surprise to see the Irish Supreme Court's careful observance of UK case law.

The final country of this category is Luxembourg. The Luxembourgish legal system has been influenced to a great extent by its neighbouring countries, such as France (mostly its civil code and civil procedure) ${ }^{48}$ and Belgium (for its commercial and criminal codes, as well as its constitutional system) ${ }^{49}$ Thus, it seems logical that the overwhelming majority of references from the Luxembourg Supreme

${ }^{41}$ G. Hamza, 'Symposium über den Einfluss des deutschen Rechtsdenkens in Mitteleuropa', 23 European Review of Private Law (2015), p. 1121.

42 S.C. Symeonides, 'The Mixed Legal System of the Republic of Cyprus', 78 Tulane Law Review (2003), p. 441.

${ }^{43}$ Ibid.

${ }^{44}$ N.E. Hatzimihail, ‘Cyprus as a Mixed Legal System’, 6 Journal of Civil Law Studies (2013), p. 95.

${ }^{45}$ P. Giliker, 'Comparing UK and Irish law: A Special Relationship?’, 47 Common Law World Review (2018), p. 3.

${ }^{46}$ B. Carolan, 'The Search for Coherence in the Use of Foreign Court Judgments by the Supreme Court of Ireland', 12 Tulsa Journal of Comparative \& International Law (2004), p. 123.

${ }^{47}$ The citations of the Irish Supreme Court made to the pre-independence House of Lords cases have been included in our study given the continuity of the House of Lords as the judicial organ.

48 L.-H. Gaicio and A. Risser: Legal systems in Luxembourg: overview, available at https://uk.practicallaw.thomsonreuters.com/w-0182382 ?transitionType=Default\&contextData $=($ sc. Default $) \&$ firstPage $=$ true

49 European E-justice: Luxembourg, available at https://e-justice.europa.eu/content_member_state_law-6-luen.do?member=1. 
Court (Cour de Cassation) ${ }^{50}$ concern the French Supreme Court (45 citations), and - to a lesser degree - the Belgian Supreme Court (12 citations).

As noted above, 'true followers' tend to be small jurisdictions whose positive law follows the law of another country. Apart from the historic ties between these countries, there is another factor which is worth considering: language. At least to some extent, all these country pairs share the same official language. For Austria and Germany, it is German; for Ireland and the UK, it is English (even though the first official language of Ireland is Irish, English has an equal status to Irish ${ }^{51}$ ). France and Luxembourg share the French language, which remains the main legal language in Luxembourg, despite Luxembourgish also being an official language. ${ }^{52}$ The only partial outlier is Cyprus, given that in 1960 Greek and Turkish replaced English as the official language of the country. ${ }^{53}$ Nevertheless, it took three decades for Greek to replace English as the language of the judiciary, and even today English terms and sources are used in court proceedings. ${ }^{54}$ This explains why the overwhelming majority of Cypriote court references cite UK and not Greek case law.

Finally, it is noteworthy that jurisdictions falling into the category of 'true followers' belong to diverse legal families. Austria and Luxembourg are civil law countries, belonging to the Germanistic and Romanistic legal branch respectively, ${ }^{55}$ while Ireland and Cyprus (the latter to a lesser extent, as explained above) are common law countries. This is an interesting observation, as it shows that the legal family of a supreme court does not necessarily determine its openness to cite the case law of foreign supreme courts.

\section{B. 'True comparatists'}

Courts characterised as 'true comparatists' satisfy three criteria. First, they have made more than 10 references to foreign supreme courts. Second, they have made foreign references in more than $1 \%$ of their cases (i.e. more than 10 references per 1000 cases). Third, they have made less than $66 \%$ of their citations to a single supreme court. ${ }^{56}$ In brief, true comparatists are therefore supreme courts that have made many references to a variety of courts. These are, as shown in Figure 3, the UK Supreme Court (58 citations), the Court of Appeal of Malta (Qorti ta'l-Appell; 299 citations) and the Supreme Court of the Netherlands (Hoge Raad; 221 citations). They shall be discussed in turn.

\footnotetext{
${ }^{50}$ Note that these are all citations by the court itself, not its advocates general; see section 4.B, below.

${ }^{51}$ See Article 8 of the Irish Constitution of 1937.

52 Le Gouvernement du Grand-Duché de Luxembourg: Use of languages in the Luxembourg courts, available at https://guichet.public.lu/en/citoyens/citoyennete/voies-recours-reglement-litiges/frais-avocat/langues-tribunaux.html.

53 Article 3(1) of the Cypriot Constitution of 1960.

${ }^{54}$ N.E. Hatzimihail, 6 Journal of Civil Law Studies (2013), p. 95.

${ }^{55}$ For the frequent divide between Germanistic and Romanistic (or German and French) forms of the civil law tradition see e.g. M. Siems, Comparative Law (2nd edn, Cambridge University Press 2008), p. 88-94.

${ }^{56}$ See section 2, above.
} 

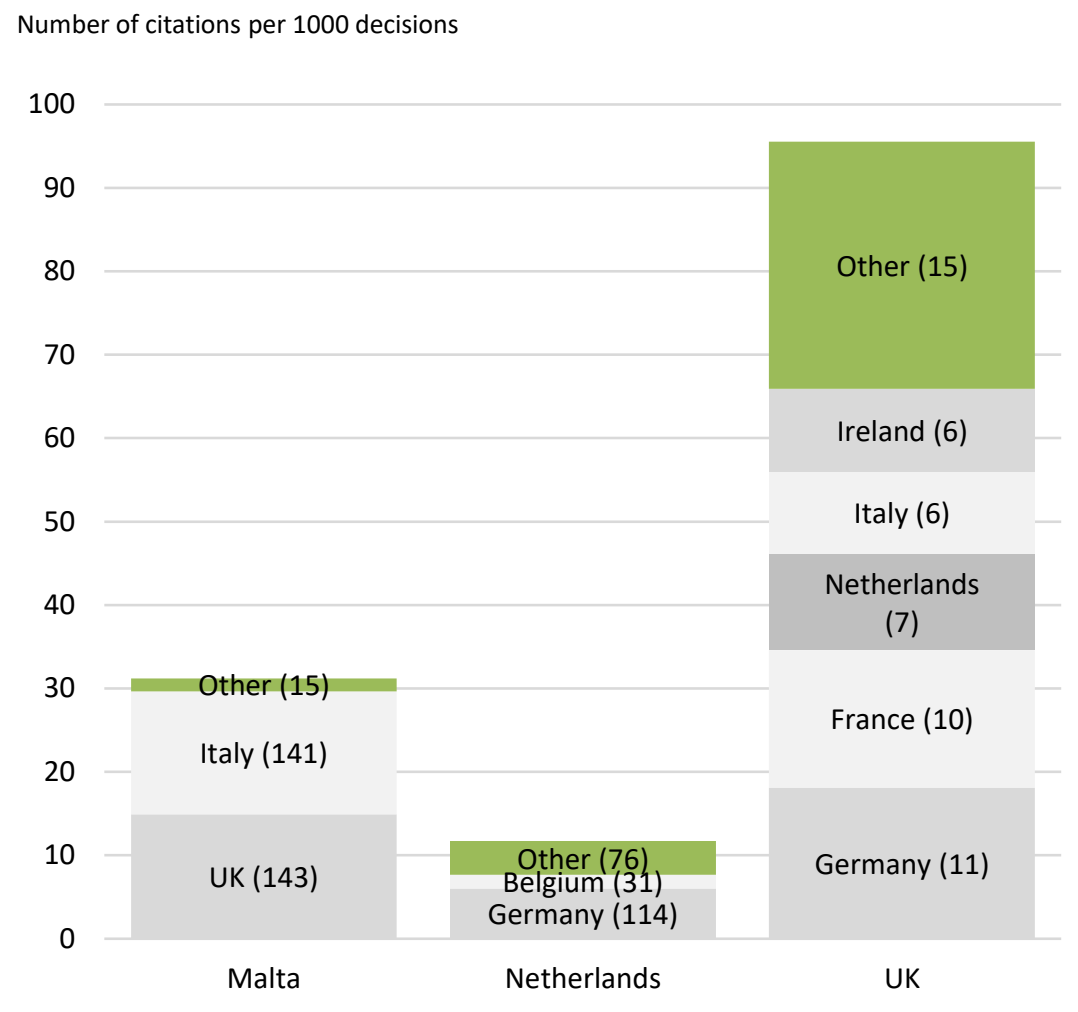

Explanatory note: as Figure 2

Figure 3. Cross-citations of the supreme courts of Malta, the Netherlands and the UK

While the absolute number of references made by the UK Supreme Court is not remarkable (58 citations), its low caseload means that it has the second highest number of references per 1000 cases out of all supreme courts (95.55). Its citations are relatively evenly distributed amongst the 14 cited supreme courts, with no apparent outliers (thus contrasting with the Irish and Cypriot supreme courts, discussed previously, that frequently cite their UK counterpart but few other courts). Perhaps ironically, the UK Supreme Court seems to have been willing to engage with ideas coming from a large spectrum of supreme courts from (as it was at the time of the data collection) other EU countries. This presents a stark contrast to the dispersion of citations of the 'true followers', ${ }^{57}$ and to smaller extent to the Dutch and Maltese supreme courts. Specifically, the UK Supreme Court has engaged most often with the German, French, Dutch, Italian and Irish supreme courts (see Figure 3). Other instances of cited supreme courts included Belgium and Austria (5 citations), Croatia (2 citations), and Finland, Greece, Lithuania, Poland, Portugal, and Spain with a single citation each. ${ }^{58}$

\footnotetext{
${ }^{57}$ See section 3.A, above.

${ }^{58}$ Even more frequently, the UK Supreme Court cites courts from Commonwealth jurisdictions, see T. Gyorfi, 'The Supreme Court (House of Lords) of the United Kingdom', in A. Jakab, A. Dyevre and G. Itzcovich (eds.), Comparative Constitutional Reasoning (Cambridge University Press 2017), p. 679, 706 (in a sample of 40 cases finding, e.g., 12 references to case law from Canada and 10 to case law from New Zealand); $\mathrm{H}$. Tyrrell, Human Rights in the UK and the Influence of Foreign Jurisprudence, p. 97-8 (reporting data on frequent citations to courts from Australia, the US, Canada and New Zealand).
} 
There are many ways in which these results could be explained. One relates to the English conception of the judicial function. In response to questions of why they cite foreign decisions, some UK Supreme Court judges have reported that they felt a sense of duty to explain to the parties why their arguments were rejected, as well as a sense of duty to openly cite a foreign court as a matter of courtesy if they have followed the foreign court's reasoning. ${ }^{59}$ In a similar vein, the House of Lords - the UK Supreme Court's predecessor - has historically been a comparative institution, with a long tradition of consulting and referencing decisions of many other common law courts. ${ }^{60}$ Citing foreign decisions has been institutionally encouraged. ${ }^{61}$ With the increased prominence of European law in the past decades, it could be that the comparative ethos ingrained into the institutional DNA of the Supreme Court was simply extended to citations of other European supreme courts. ${ }^{62}$ In this European context, UK Supreme Court judges have reported that the prestige of the cited court is an important determinant of their willingness to cite, ${ }^{63}$ which also in part explains the distribution of citations we have discovered.

There are also more tangible ways in which the internationalised and Europeanised nature of the UK's (and particularly England's) legal order has manifested. There are many foreign, especially European lawyers working in the UK, bringing their continental background and legal thinking with them. ${ }^{64}$ Moreover, England is an extremely popular choice of venue jurisdiction in many international commercial contracts. ${ }^{65}$ Even though the jurisdiction might be English, the parties may agree on foreign, and not English law when governing the dispute. Thus, many commercial lawyers and judges in England are forced, on a regular basis, to argue cases governed by foreign law, further normalising the presence of foreign decisions in the culture of domestic judicial decision-making and justification.

Lastly, even though UK Supreme Court judges echo the classical language restraint argument found in the comparative law literature, reporting that they feel uncomfortable consulting materials in German or French, ${ }^{66}$ there has long been abundant literature on foreign and comparative law published in English as the lingua franca ${ }^{67}$ In this way, despite the obvious language barriers, judges have had ample opportunities to consult authoritative texts on foreign law in English. Moreover, given the relatively low caseload of the UK Supreme Court, the judges can deal with the cases it decides in more detail, including considering comparative literature and case law from other European courts.

As for the Court of Appeal of Malta, the distribution of its citations has been considerably less equal compared to that of the UK. From 2000 to 2018, the Court has produced an estimated 299 citations,

\footnotetext{
${ }^{59}$ E. Mak, 'Why Do Dutch and UK Judges Cite Foreign Law', 70 Cambridge Law Journal (2011), p. 444.

${ }^{60}$ E. Mak, 'Reference to Foreign Law in the Supreme Courts of Britain and the Netherlands: Explaining the Development of Judicial Practices', 2 Utrecht Law Review (2012), p. 8, 32; E. Mak, 70 Cambridge Law Journal (2011), p. 436; E. Örücü, 'Comparative Law in British Courts', in U. Drobnig and S. van Erp (eds.), The Use of Comparative Law by Courts (Kluwer Law International, 1999); M. Andenas and D. Fairgrieve, in M. Andenas and D. Fairgrieve (eds.), Tom Bingham and the Transformation of the Law: A Liber Amicorum, p. 840

${ }^{61}$ See Practice Directions issued by the Lord Chief Justice in 2001 [2001] 2 All ER 510; E. Mak, 'Why Do Dutch and UK Judges Cite Foreign Law', 70 Cambridge Law Journal (2011), p. 429.

${ }^{62}$ See Introductory speech by Lord Bingham at the launch of WV Gerven Tort Law: Scope of Protection (Hart 1998) in Gray's Inn, May 1998 in in M. Andenas and D. Fairgrieve (eds.), Tom Bingham and the Transformation of the Law: A Liber Amicorum, p. 843. See also Lord Justice Mance, 36 Texas International Law Journal (2001), p. 415.

${ }^{63}$ E. Mak, 70 Cambridge Law Journal (2011), p. 436.

${ }^{64}$ Lord Bingham, 41 International and Comparative Law Quarterly (1992), p. 513. On the role of lawyers bringing comparative arguments before the Supreme Court, see E. Mak, 'Why Do Dutch and UK Judges Cite Foreign Law', 70 Cambridge Law Journal (2011), p. 429.

${ }^{65}$ In cases before the Commercial Court (England and Wales), one of the parties is foreign in most cases and both parties are foreign in half of cases. See M. Andenas and D. Fairgrieve, in M. Andenas and D. Fairgrieve (eds.), Tom Bingham and the Transformation of the Law: A Liber Amicorum, p. 838.

${ }^{66}$ E. Mak, 70 Cambridge Law Journal (2011), p. 446.

${ }^{67}$ Lord Bingham, 41 International and Comparative Law Quarterly (1992), p. 527.
} 
which translates to 31.2 citations per 1000 cases. It cited 9 different supreme courts from other European countries, with citations to the supreme courts of the UK (estimated 143 citations ${ }^{68}$ ) and Italy (141 citations) heavily dominating the citation pattern. Occasionally, the Court also cited the supreme courts of France (5 times), Austria (4 times), Bulgaria (2 times), as well as Belgium, Germany, Greece and the Netherlands (once).

The high number of citations and their distribution may be explained, to a significant extent, by the mixed legal nature of the Maltese legal system and its complex historical development. While its history is too rich to discuss in detail, ${ }^{69}$ it suffices to say that Maltese law has been affected by a variety of continental legal systems and the British common law system. The underlying continental influence was that of Roman and canon law; with more specific influences from Sicily, Italy, and France playing an important role throughout the previous millennium until British colonial rule between 1800 and $1964 .{ }^{70}$ The mixing of common and civil law traditions during colonial times did not make the legal system of Malta a 'melted' mixed legal system in which elements of the common and civil law would be interwoven. Instead, much like in Cyprus, the mix of common law and civil law was more clear-cut as they were left to operate independently in their own discrete legal areas. Private law remained in the domain of civil law, whereas common law took over public, commercial, and procedural law.

It is no surprise that in a system so heavily influenced by foreign law, its jurisprudence is also 'truly comparatist'. Indeed, this intense interplay of various influences throughout Maltese history has led 'Maltese jurists to become natural comparatists, ${ }^{, 71}$ some have argued. One of the most significant pieces of legislation in Maltese history, the Code de Rohan (1784), included a provision permitting domestic courts to resort to 'opinions of the Supreme and most authoritative [foreign] Courts' when resolving

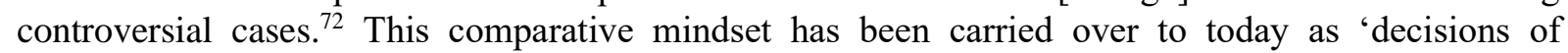
international or foreign courts applying similar legal principles' are still considered as 'evidential' sources of law. ${ }^{73}$

The linguistic diversity of Malta also helps to explain the observed distribution of its citation pattern, in which Italy and the UK dominate. Maltese, a Semitic language influenced by Sicilian and Italian, has historically been the primary colloquial language in Malta, whereas Latin and later Italian were the languages of the law, even during the British rule. ${ }^{74}$ Despite being widely spoken, Maltese was only accepted as the official language of Malta in 1934, while Italian remained the official language of Malta

\footnotetext{
${ }^{68}$ For the need to estimate the number of citations in this case see section 4.C, below.

${ }^{69}$ For in-depth accounts of the development of law in Malta, see S.P. Donlan, D. Andò and D.E. Zammit, ““A Happy Union”? Malta's Legal Hybridity', 27 Tulane European and Civil Law Forum (2012), p. 165; K. Aquilina, 'Rethinking Maltese Legal Hybridity: A Chimeric Illusion or a Healthy Grafted European Law Mixture Conference Proceedings: Mediterranean Legal Hybridity: Mixtures and Movements, the Relationship between the Legal and Normative Traditions of the Region Malta, June 11-12, 2010', 4 Journal of Civil Law Studies (2011), p. 261; P.J. Galea, 'A Brief Overview of Malta, a RomanCivil Law Country, with Common Law Adoption as Rules of Civil Evidence Paper', 5 Digital Evidence and Electronic Signature Law Review (2008), p. 202.

${ }^{70}$ For this and the following statements of this paragraph see B. Ando, 'The Role of Judges in the Development of Mixed Legal Systems: The Case of Malta', 4 Journal of Civil Law Studies (2011), p. 239.

${ }^{71}$ U.M. Bonnici, An Introduction to Comparative Law (Malta University Press, 2004), p. 11.

${ }^{72}$ D. Ando, 4 Journal of Civil Law Studies (2011), p. 260.

${ }^{73}$ D.J. Attard, The Maltese Legal System. Volume I (Malta University Press, 2012), p. 26.

${ }^{74}$ S.P. Donlan et al., 27 Tulane European and Civil Law Forum (2012), p. 176, 184.
} 
until 1939. ${ }^{75}$ Today, Maltese and English are the official languages, with $98 \%$ of Maltese people fluent in Maltese, $88 \%$ in English, $66 \%$ in Italian, and about $17 \%$ in French. ${ }^{76}$ Even though today judgments are drafted in Maltese, the Maltese used in courts is not the colloquial Semitic Maltese but 'Italianate' Maltese, heavily influenced by legal Italian. ${ }^{77}$ The polyglottism of the Maltese and the openness of its legal system are also demonstrated by the fact that the Maltese court refers to most of the citations of its UK and Italian counterparts in the original language.

The Dutch openness to making foreign citations is also rooted in its legal history. Already in 1999, van Erp spoke of an 'increasingly more open legal mind and hence an ever-growing use of the comparative law method by the judiciary' in the Netherlands. ${ }^{78}$ Our data support his observation. The Supreme Court of the Netherlands (Hoge Raad) produced 221 total citations, citing 15 of the other supreme courts. The highest number of citations to the German Supreme Court (114 times), followed by those of Belgium (31 times), France (21 times), the UK (20 times), Austria (13 times), Italy (6 times ), Sweden, (4 times), Denmark, Greece, Luxembourg, and Spain (2 times each), and the Czech Republic, Hungary, Ireland and Slovenia (once each).

Most citations were made by advocates general in their opinions, and not directly by the Court itself, which has been unwilling to refer to foreign judgments ${ }^{79}$ due to its argumentation style. This is based on, and closely resembles, the laconic style of the French Cour de cassation. ${ }^{80}$ Extrajudicially, judges themselves have openly referred to opinions of advocates general as giving more of an 'insight into the background for the Court's reasoning. ${ }^{81}$ Indeed, the citations in the opinions are often quite thorough with citations to foreign courts in their original language (in particular those of the German, French, Belgium and UK supreme courts). Even though it is sometimes not entirely clear if a particular reference to a foreign court is decisive for the argument, such an approach reflects and confirms the general impression that Dutch judges and advocates general possess a certain linguistic prowess, enabling them to consult foreign doctrine in a variety of different languages. ${ }^{82}$

Our data supports the reports of the Hoge Raad judges that state they most often consult decisions of the German Supreme Court but also the French and UK courts. ${ }^{83}$ The data also concurs with statements made by the advocates general, who assert that they are influenced by the perceived expertise of foreign courts in specific areas of the law, referring particularly to the expertise of the German Supreme Court. ${ }^{84}$ Note that this is a variation of the 'prestige of the court' argument, akin to the situation observed for the UK Supreme Court.

\footnotetext{
${ }^{75}$ Ibid. p. 176.
}

76 European Commission, Special Eurobarometer 386: Europeans and Their Languages (2012), https://ec.europa.eu/commfrontoffice/publicopinion/archives/ebs/ebs_386_en.pdf. The lack of French speakers in Malta may also explain the relative lack of citations to the French Cour de cassation, despite the later codification of Maltese private law being heavily based on the 1804 Code Napoléon. See D.J. Attard, The Maltese Legal System. Volume $I$, p. 22. The formulaic and laconic argumentative style of the Cour de cassation could also contribute to the unwillingness of the Court of Appeal to cite French judgments.

${ }^{77}$ D. Zammit and K. Xerri, “'Lease, Locazioni and Kera”: Merging Legal Concepts in Postcolonial Malta', in S. Farran et al. (eds.), The Diffusion of Law: The Movement of Laws and Norms around the World (Ashgate, 2015), p. 88.

${ }^{78}$ S. van Erp, 'The Use of the Comparative Law Method by the Judiciary - Dutch National Report', in U. Drobnig and S. van Erp (eds.), The Use of Comparative Law by Courts (Kluwer Law International, 1999), p. 252.

79 A.S. Hartkamp, 'Comparative Law Before the Dutch Courts', in G. Canivet, M. Andenas and D. Fairgrieve (eds.), Comparative Law Before the Courts (British Institute of International and Comparative Law 2004), p. 229; T. Koopmans, 'Comparative Law and the Courts', 45 The International and Comparative Law Quarterly (1996), p. 550.

${ }^{80}$ E. Mak, 70 Cambridge Law Journal (2011), p. 431. For France see section 3.D, below.

${ }^{81}$ E. Mak, 70 Cambridge Law Journal (2011), p. 445.

${ }^{82}$ M. Gelter and M. Siems, 8 Utrecht Law Review (2012), p. 97; E. Mak, 70 Cambridge Law Journal (2011), p. 447.

${ }^{83}$ E. Mak, 70 Cambridge Law Journal (2011), p. 439.

${ }^{84}$ Ibid. 
Furthermore, the Dutch legal culture cannot be overlooked as an explanation of its propensity to cite foreign decisions. Dutch private law has historically been heavily influenced by foreign legal ideas and developed through comparative rationales: the old Dutch Civil Code was largely a duplicate of the French Civil Code, while the new Dutch Civil Code was developed through a rigorous comparative research of mostly Germanic civil codes. ${ }^{85}$ This has contributed to the development of an open legal culture and rendered it normal for Dutch courts to look at how particular issues have been dealt within the legal system from which the Dutch Civil Code originated. ${ }^{86}$ This historical background also helps to explain the distribution of the citation pattern. In particular it explains the citations to the German Supreme Court, but also the reasonably high number of citations of the French court (which may have been higher were it not for its formulaic and laconic argumentative style). ${ }^{87}$

Overall, as in the previous sub-section, this sub-section also demonstrates that comparative citations of foreign decisions are not in the exclusive domain of a single legal tradition. Fittingly, the three true comparatists (the UK Supreme Court, the Dutch Hoge Raad, and the Maltese Court of Appeal) represent the three major legal traditions found in Europe (common law, civil law and mixed law systems respectively). Our data also shows that citing foreign decisions is not unique to a single argumentation style. Here again, the three courts represent the two extremes and one in-between: we have found abundant citations in the lengthy discursive treatise of UK judges, in the moderately long decisions of the Maltese court and in the concise Dutch judgments (though the latter are supplemented by more elaborate opinions of its advocates general).

\section{C. 'Reluctant followers'}

The following two sub-sections discuss the categories of reluctant followers and reluctant comparatists, namely courts of countries with more than 10 cross-citations, but with relative numbers of citations falling below $1 \%$. As in the previous two sub-sections, a further distinction is made between supreme courts that mainly cite the court of one other country, and supreme courts that cite a variety of foreign courts. This sub-section discusses the supreme courts of countries with a monogenous citation pattern in more detail, given that more than $66 \%$ of their citations were to a single foreign supreme court.

\footnotetext{
${ }^{85}$ A.S. Hartkamp, in G. Canivet, M. Andenas and D. Fairgrieve (eds.), Comparative Law Before the Courts, p. 231; T. Koopmans, 45 The International and Comparative Law Quarterly (1996), p. 545.

${ }^{87}$ But see also S. van Erp, in U. Drobnig and S. van Erp (eds.), The Use of Comparative Law by Courts, p. $244-45$ (arguing that the historically prominent influence of French law in Dutch private law is no longer reflected in citation patterns).
} 
Number of citations per 1000 decisions

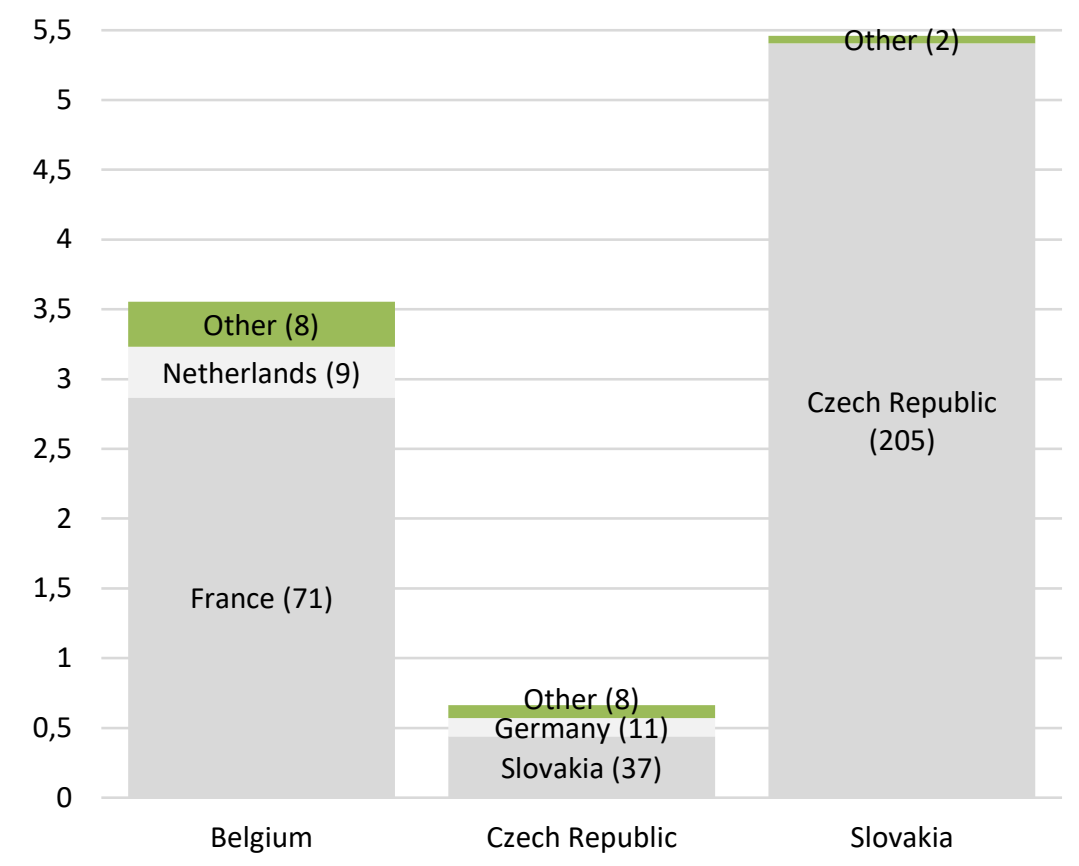

Explanatory note: as Figure 2

Figure 4. Cross-citations of the supreme courts of Belgium, the Czech Republic and Slovakia

Three courts are classified as 'reluctant followers': Belgium, Slovakia and the Czech Republic. The Supreme Court of Slovakia (Najvyšši súd) almost only referred to the Supreme Court of the Czech Republic (in 205 cases, in addition to single references to Germany and Austria); yet, it did so in a fairly large number of decisions both in absolute and in relative terms (see Figure 4). The Supreme Court of the Czech Republic (Nejvyšš soud) has, by comparison, a more heterogeneous citation style, as it referred predominantly to Slovakia (in 37 cases, i.e. 66\%), but also to Germany (11 times), Austria (3 times), the Netherlands ( 2 times) and France, Italy and Poland (once each). Likewise, the Supreme Court of Belgium (Cour de cassation, Hof van Cassatie) refers predominantly to France (in 80\% of the cases), but also to the Netherlands, Germany and to some other countries in a smaller proportion.

Indeed, the fact that both Slovakia and the Czech Republic fall under this category may be explained historically, given that for the most of the twentieth century (1918-1992) they formed part of a single country. Thus, they share history, legal traditions, as well as the experience of being a transition country. ${ }^{88}$ Prima facie, it is apparent that the Slovak court engages with Czech case law much more frequently (205 references) than the Czech court with the Slovak one (37 references). Yet, it is crucial to consider that the great majority of the Slovak references to the Czech Supreme Court were made in the context of the claimant's or the lower's court argumentation (and, thus, one may draw a parallel to the countries in which cross-citations are mainly in the opinions of the advocates general). While a vast number of references appears in the same context, i.e. the Supreme Court merely mentions the fact that one of the parties has referred to a given judgment of the Slovak Supreme Court in the prior proceedings, there are also cases where the Czech Supreme Court refers to the Slovak case law in its own

\footnotetext{
${ }^{88}$ Note that we did not include cases in which the Czech and Slovak Supreme Courts cited decisions of the former Supreme Court of Czechoslovakia. Our interest is limited to citations between the courts mentioned in Table 1, above, excluding prior courts. The same applies to former Yugoslavian courts or the German Reichsgericht.
} 
argumentation. ${ }^{89}$ Thus, it can be said that the style of citations of the Czech to the Slovak Supreme Court is more mixed.

What may be surprising is the fact that neither the Slovak nor the Czech court refer to the Austrian Supreme Court. This is despite the fact that the Austrian Civil Code (ABGB) was effective in Czechoslovakia until 1964, and some traces of the Austrian civil law institutions remain visible to date, particularly in the Czech Republic..$^{90}$ Moreover, the German Civil Code (BGB) has exerted significant influence on the current Czech Civil Code (introduced in 2014), which may account for the German court being the second most-cited by the Czech court. ${ }^{91}$ In the case of Slovakia, another intriguing fact is the absence of references to Hungarian law, even though Hungarian private law was valid and applied on the territory of Slovakia until $1951 .{ }^{92}$

Overall, our findings do not confirm Bobek's view of the Slovak Supreme Court as 'an example of institutional and cultural settings which [is] hostile to any open use of comparative reasoning or any persuasive argument generally ${ }^{93}$, where 'comparative reasoning is as good as non-existent' ${ }^{94}$ While it is true that the Slovak Supreme Court does not openly engage with the Czech courts' reasoning as an interpretative aid, it cannot go unnoticed that the parties' and/or lower instances' statements have at least an indirect influence.

With regards to the third country in the 'reluctant followers' category, the Belgian Cour de Cassation has predominantly cited its French counterpart (in 71 out of 88 cases).$^{95}$ This is hardly surprising given that Belgian private law descends from the Napoleonian Code and is still today highly inspired by French law and case-law. ${ }^{96}$ French legal scholars are largely referred to in Belgian scholarship, and the Belgian Cour de Cassation has often transposed developments of its French counterpart in relation to contract law. ${ }^{97}$ French developments and reforms were also referred to when reforming Belgian contract law. ${ }^{98}$ However, this tendency is one sided since - as shown in the next sub-section - the French Cour de Cassation refers less frequently to the Belgian Court in its judgments. The other courts cited by the Belgian court are the Netherlands ( 9 citations), Germany (5 citations), Denmark ( 1 citations), the UK (1 citations) and Italy (1 citations). References to the Dutch and German court may be explained by the linguistic situation in Belgium, as Dutch and German (together with French) are the official languages of Belgium. Additionally, it may be explained by the common history that Belgium shares with the

\footnotetext{
${ }^{89}$ E.g. 30 Cdo 509/2018; 20 Cdo 2302/201.

${ }^{90}$ P. Dostalík and O. Horák, 'Zmiany w czeskim prawie prywatnym', Forum Prawnicze (2014), p. 16.

91 Ibid.

92 The same remark has been made by Bobek with regard to the Slovak Constitutional Court, see M. Bobek, Comparative Reasoning in European Supreme Courts, p. 182.

${ }^{93}$ Ibid. p. 185.

${ }^{94}$ Ibid. p. 174.

95 This included the opinions of the advocates general of the Belgian Cour de Cassation, see section 2 above.

${ }^{96}$ See S. Bouabdallah, La réception du modèle français en droit civil belge-exemple d'un transfert de droit (Editions Bruylant, 2014).

${ }^{97}$ P. Wéry, 'Mutations et défis du droit belge des obligations', 2 Revue de la Faculté de droit de l'Université de Liège (2015), p. 211.

98 M. Latina, 'L'avant-projet de réforme du droit des obligations... belge', 28.05.2018; available at https://actu.dallozetudiant.fr/le-billet/article/lavant-projet-de-reforme-du-droit-des-obligationsbelge/h/a31ce916472273b5fc124af69f319d1b.html.
} 
Netherlands, although Belgian law is much less influenced by German and Dutch law than by French law. ${ }^{99}$

To conclude, the categorisation the aforementioned 'reluctant followers' can be plausibly explained by historical, linguistic and geographical reasons. Belgium, Slovakia and the Czech Republic are relatively small jurisdictions that have been influenced by their neighbouring countries. Much as in the case of 'true followers', this category encompasses countries of different legal traditions. While the influence of Slovakia and the Czech Republic was mutual, given their shared history, the relationship between the Belgian and the French court is more asymmetric.

\section{D. 'Reluctant comparatists'}

The category of 'reluctant comparatists' includes the nine countries shown in Figures 5a, 5b and 5c on a different scale based on the relative frequency of their citations: Denmark, Germany and Sweden (all with more than five citations out of 1000 decisions), Lithuania, Poland, Portugal and Slovenia (all with less than five but more than 0.5 citations out of 1000 decisions) and France, Italy and Spain (all with less than 0.5 citations out of 1000 decisions). This group is highly heterogenous, comprising countries from different legal traditions and geographical regions, which makes it difficult to find a common denominator for the reasons behind their citation patterns. In what follows, we briefly present findings for each country. We first discuss Germany as the country with the highest number of foreign references, followed by countries that have been highly influenced by it (Poland, Slovenia and Lithuania). Then, we move on to the Romanistic civil law countries (Italy, France, Spain and Portugal) ${ }^{100}$ and then the two Nordic countries (Denmark and Sweden).

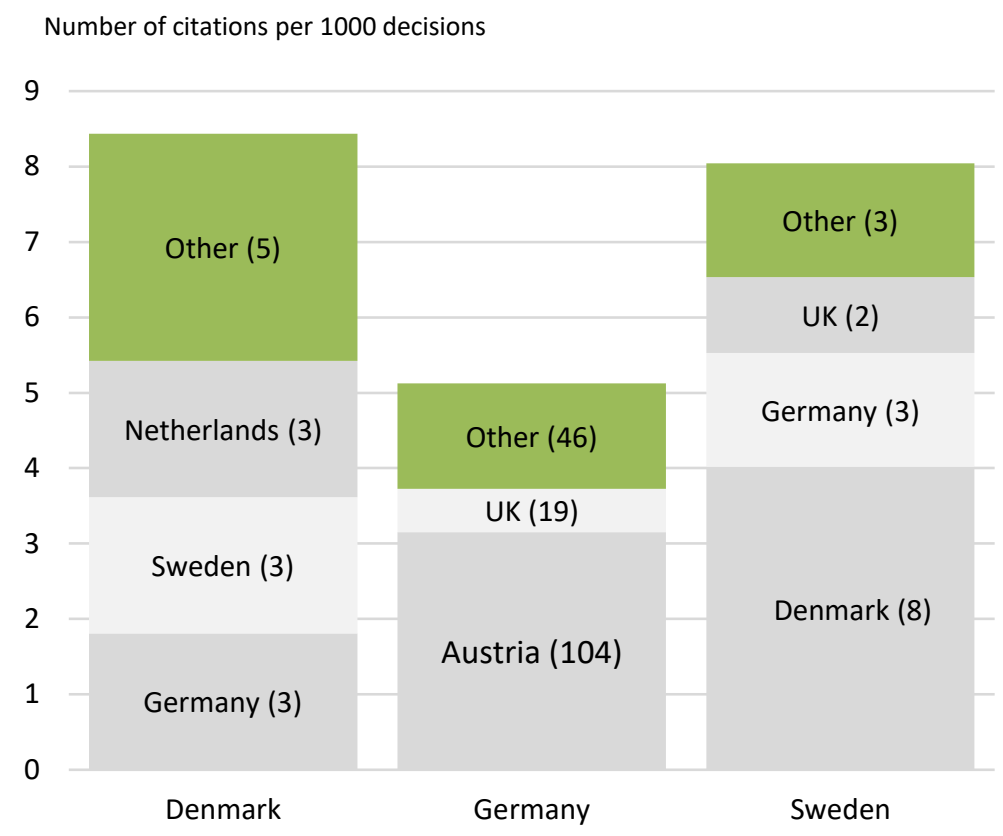

Explanatory note: as Figure 2

Figure 5a. Cross-citations of the supreme courts of Denmark, Germany and Sweden

\footnotetext{
${ }^{99}$ See D. Heirbaut and M. Storme 'The Belgian Legal Tradition: From a Long Quest for Legal Independence to a Longing for Independence', 5/6 European Review of Private Law (2004), p. 645.

${ }^{100}$ For this category see above note 55.
} 
Number of citations per 1000 decisions

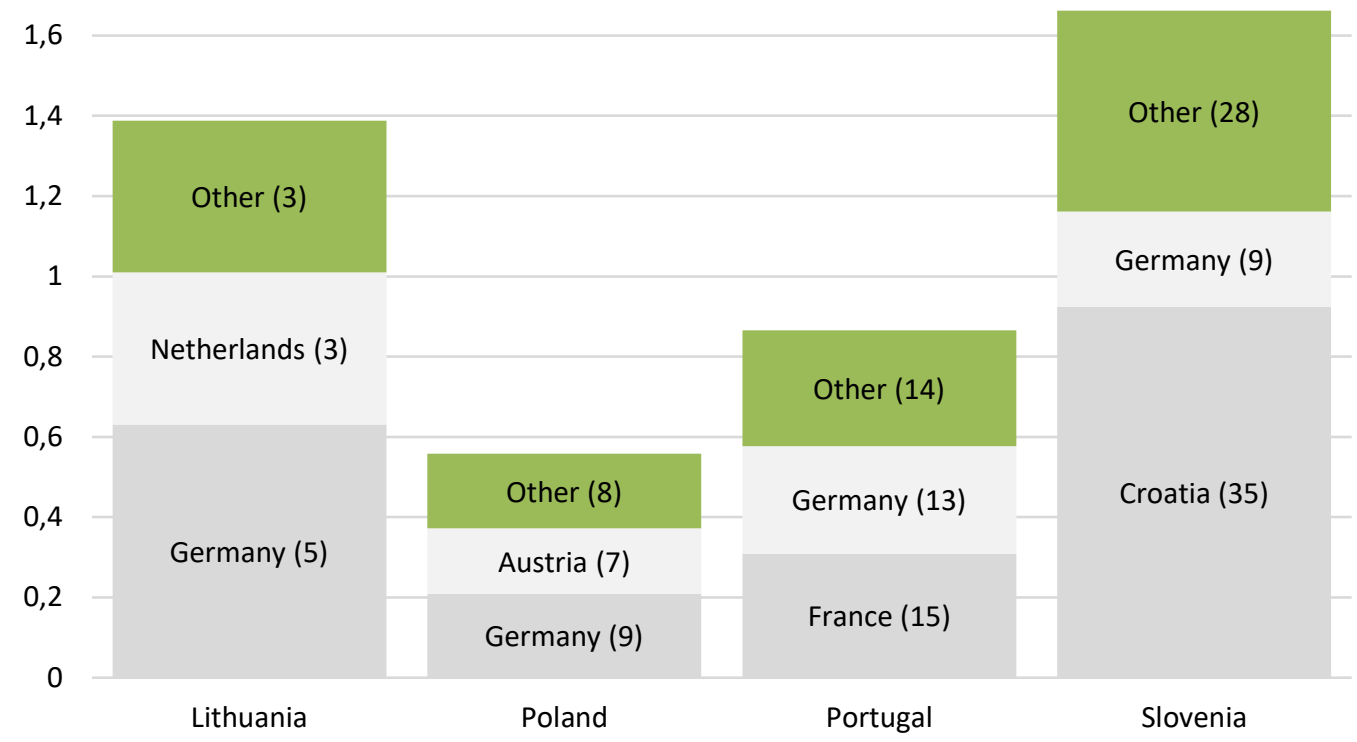

Explanatory note: as Figure 2

Figure 5b. Cross-citations of the supreme courts of Lithuania, Poland, Portugal and Slovenia

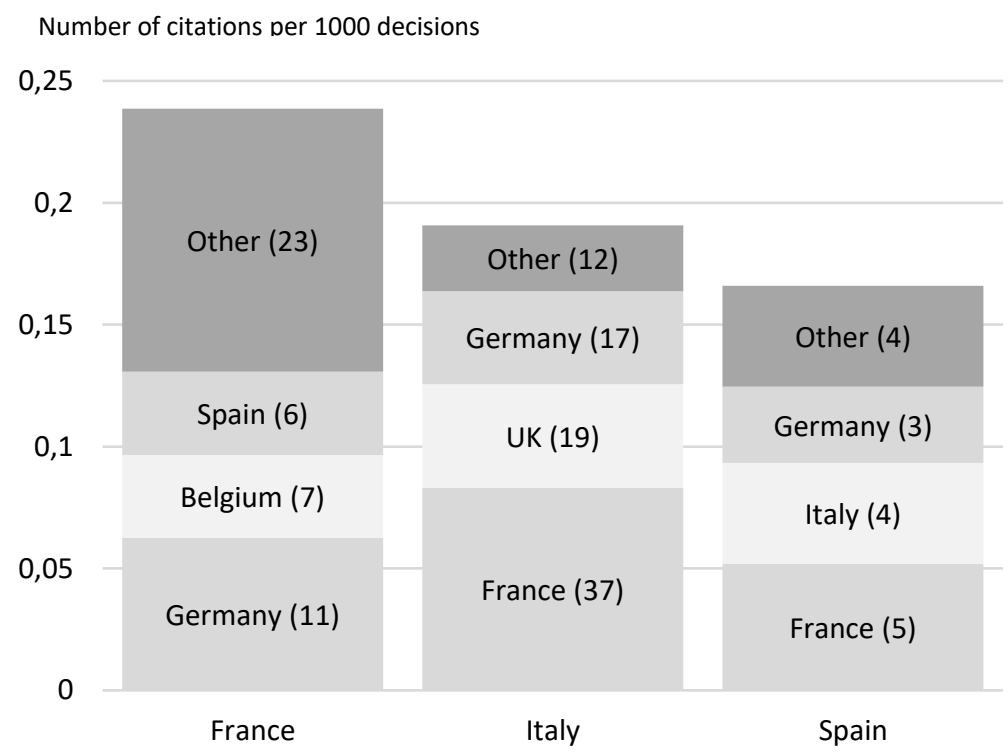

Explanatory note: as Figure 2

Figure 5c. Cross-citations of the supreme courts of France, Italy and Spain 
In Germany, the Federal Supreme Court (Bundesgerichtshof) referred to Austria in 104 out of 169 cases. Its other most frequent citations were made to the UK (19 times), Italy (12 times), France (10 times) and the Netherlands (10 times). Fewer references have been made to Spain, Belgium, Hungary, Ireland and Sweden. It is, thus, interesting to observe that with around $61.5 \%$ of citations to Austria, it is on the verge of a classification as a 'reluctant follower'. The influence between Austrian and German court decisions is mutual (noting that Austrian court frequently cites the German one). ${ }^{101}$ However, more detailed analysis of the references of both supreme courts reveals that, while the Austrian court tends to properly employ a comparative reasoning in its judgments, the references of the German court are predominantly ornamental and do not engage with the quoted judgments in detail. ${ }^{102}$ This observation is also true for references made by the German court to other foreign courts. In general, it can be said that the German Supreme Court is often detailed in its legal argumentation and it supports its reasoning with extensive references to domestic judgments (be it to its own decisions, or to lower court instances) and academic literature. Yet, the foreign case-law plays only a marginal role in its argumentation. ${ }^{103}$

The Slovenian Supreme Court (Vrhovno sodišče) cited Croatia in over half of its references to foreign supreme courts ( 35 out of 63 cases, i.e. 55\%). Other references included Germany ( 9 citations), Austria (8 citations) and Italy (8 citations). Additionally, singular references were made to the UK, the Netherlands and France. The dominance of citations to the Croatian Supreme Court may be explained by a number of factors, such as the geographical vicinity, shared history (Slovenia and Croatia were both part of Yugoslavia until 1991), and the fact that Croatian is a commonly spoken language in Slovenia. Moreover, it is interesting to note that many decisions referring to the Croatian Supreme Court ${ }^{104}$ concerned the Convention on the Law Applicable to Traffic Accidents. ${ }^{105}$ The high number of references to the German Supreme Court may reflect the influence of the German legal system, which has been traditionally considered as 'best practice' in the Slovenian legal academia and many pieces of Slovenian legislation have been heavily influenced by German statutes. ${ }^{106}$ The citations to the Austrian Supreme Court may be explained by the geographical proximity of Austria to Slovenia as a significant number of these cases had a cross-border element. The number of citations to the Italian Supreme Court may be due to the relatively high number of Italian speakers in Slovenia because of the big Italian community residing there. ${ }^{107}$ Overall, the study's findings confirm that after independence, Slovenia underwent the process of 'Europeanisation' of its legal system. ${ }^{108}$

Another 'reluctant comparatist' is Poland, with 24 references in total. The foreign supreme courts most frequently cited by the Polish Supreme Court (Sad Najwyższ) were the German and Austrian Supreme Courts ( 9 and 7 citations) with few references to those of Greece ( 2 citations), France ( 2 citations), Italy, the Netherlands, Slovakia and the UK (1 citation each). German civil law was a model for the Polish

\footnotetext{
${ }^{101}$ See section 3.1, above. For a detailed account of influence of the BGB on the Austrian private law, see E.A. Krammer, 'Der Einfluß des BGB auf das schweizerische und österreichische Privatrecht', 200 Archiv für die civilistische Praxis (2020), p. 37.

${ }^{102}$ M. Gelter and M. Siems, 62 American Journal of Comparative Law (2014), p. 80.

103 M. Bobek, Comparative Reasoning in European Supreme Courts, p. 146.

${ }^{104}$ Citations to decisions 243/2012, 82/2014, 387/2010, 679/2009, 298/2010, 23/2010, 182/2003.

${ }^{105}$ In brief, the Croatian Vrhovni sud passed the so called 'Orientation Criteria' which in the abstract determine how the courts should assess claims for non-pecuniary damages related to traffic accidents. As a result, the Slovenian Supreme Court discussed the 'Orientation Criteria' every time a case of a Slovenian citizen who was involved in a car accident in Croatia reached the Slovenian Supreme Court. This could qualify as a statistical outlier due to this way in which Croatia regulates non-pecuniary damages in such contexts.

106 See e.g. M. Čarni, S. Košak and I. Štefanec, 'Republic of Slovenia Legal System and Legal Research', available at https://www.nyulawglobal.org/globalex/Slovenia1.html.

${ }^{107}$ See Eurobarometer, above note 76.

${ }^{108}$ G. Antonio, 'National Courts and Comparative Law - The States of Former Yugoslavia (Slovenia, Croatia, Serbia, BosniaHerzegovina, Macedonia and Montenegro)', in G. Franco Ferrari (ed.), Judicial Cosmopolitanism (Brill Nijhoff 2019).
} 
civil code introduced in 1964 which, although with numerous changes, remains in force to date. ${ }^{109}$ The German influence is visible both in terms of general principles and concepts, as well as in the construct of specific legal instruments, and the comparison of Polish and German law is also strongly embedded in Polish academic literature. ${ }^{110}$ Linguistic reasons may also explain why the German Supreme Court was the most-cited court by Polish Supreme Court judges, as German is one of the most commonly spoken foreign languages in Poland. ${ }^{111}$ With these considerations in mind, one might have even expected more references to the German law in the studied period. The relatively high number of citations to Austrian citations are some substantive references, appearing mainly in the context of conflict of jurisdictions, but also, interestingly, in cases concerning the interpretation of the Bills of Exchange and Promissory Notes.

The Lithuanian Supreme Court (Aukščiausiasis Teismas) made 11 cross-citations, namely to Germany (5 times), the Netherlands (3 times), Spain (2 times) and France (once). This may be interpreted as showing that the Lithuanian court has a potential interest in German law but also some other Western European jurisdictions (and it may also be noted that the relative frequency of these cross-citations is higher than that of the Polish court, see Figure 5b, above). Yet, the information about these crosscitations needs to be qualified as six of them are found in two near identical judgments delivered on the same day. ${ }^{112}$ Thus, it can be suggested that the foreign citation practice of the Lithuanian court is on the verge of being an 'isolate' (as the other two Baltic countries, discussed in the next sub-section).

As regards the Romanistic civil law countries, prior research has observed that in Italy and France cultural constraints speak against citing anything beside the relevant codes and status. ${ }^{113}$ Indeed, the Italian Supreme Court (Corte di Cassazione) has a relatively low rate of citation with only around 2 citations out of every 10,000 decisions. ${ }^{114}$ References are predominantly made to the French Supreme Court (37 citations out of 85), and then to the UK (19 citations), German (17 citations), Greek (10 citations), Austrian and Spanish courts (one each). However, many of these references were made within the context of sister judgments being delivered on the same day, meaning a chain of references was duplicated for each case. It can also be noted that half of the citations made by the Italian Supreme Court refer to the French Supreme Court, a tendency that is not mutual for the French court, as seen below.

The case-law of the French Supreme Court (Cour de Cassation) has a rate of citation similar to the Italian Supreme Court with a ratio of around 2 citations per 10,000 decisions. ${ }^{115}$ Since the judgments of the Cour de Cassation feature only a short deductive reasoning and rarely cite case-law, ${ }^{116}$ our analysis

\footnotetext{
${ }^{109}$ For a comprehensive overview of the influence of German law on Polish law, see R. Grzeszczak, 'Transfer myśli prawnej', available at http://www.polska-niemcy-interakcje.pl/articles/show/18.

110 Ibid.

${ }^{111}$ See Eurobarometer, above note 76.

112 Civil case no. 3K-3-305 /2013 (S); Civil case no. 3K-3-306 / 2013 (S).

113 See e.g. B. Markesinis and J. Fedtke, 'The Judge as Comparatist', 80 Tulane Law Review (2005), p. 11, 26-30; B. Markesinis and J. Fedtke, Judicial Resource to Foreign Law: A New Source of Inspiration? (UCL Press 2006), p. 62-6.

${ }^{114}$ Similar the assessment by G. Smorto, 'L'uso giurisprudenziale della comparazione', Europa e diritto private (2010), p. 223 (also referring to the fact that the few foreign references are often in the same judgments).

${ }^{115}$ Similarly, noting a very modest influence of foreign case-law: G. Canivet, 'La pratique du droit compare par les cours supremes Breves reflexions sur le dialogue des juges dans les experiences française et europeenne', 80 Tulane Law Review (2005), p. 1377.

${ }^{116}$ For the traditional approach, see e.g. M. de S.-O.-l'E. Lasser, Judicial Deliberations: A Comparative Analysis of Transparency and Legitimacy (Oxford University Press 2009) (also suggesting that in French courts judicial argumentation
} 
includes the opinions of the advocates general. ${ }^{117}$ More specifically, out of 47 citations, 11 referred to Germany, 7 to Belgium, 6 to Spain, 5 to Italy, 5 to the UK and 4 to Ireland. Other minor references were made to the supreme courts of Bulgaria, Greece and Poland (2 citations each) and Austria, the Netherlands and Portugal (1 citation each). Hence, references to the German Supreme Court are not dominant neither in absolute nor relative terms, though a degree of mutuality may be present as the German court also referred to the French in 10 cases.

Spain is the country with the lowest relative frequency of foreign citations in the category of 'reluctant comparatists', ${ }^{118}$ with the judgments of the Spanish Supreme Court (Tribunal Supremo) totalling only 16. Out of these, 5 were made to France, 4 to Italy, 3 to Germany, 2 to the UK, and 1 to Austria and Sweden. As a country of a largely French legal tradition, ${ }^{119}$ the explanation of the French, as well as of Italian influence in Spanish private law cases is straight-forward. This citation pattern of the Spanish Supreme Court in private law cases also corresponds with the one of the Spanish Constitutional Tribunal, which referred to Italy, France and Germany most frequently. ${ }^{120}$

The Portuguese Supreme Court (Supremo Tribunal de Justiça) resorted to foreign supreme courts' ruling 42 times in total, and thus with a relative frequency higher than the other three Romanistic civil law countries. ${ }^{121}$ References were made 15 times to France, 13 times to Germany, 8 times to Spain; 3 times to Italy; twice to the UK and once to the Netherlands. This finding reflects the influence of both French and German legislative models on the Portuguese law. ${ }^{122}$ While the first Portuguese Civil Code followed the model of the Napoleonic Code, German law exerted a strong impact on the further developments of Portuguese law over the course of the twentieth century. ${ }^{123}$ Furthermore, it is interesting to note that Portugal referred to Spain 8 times. By contrast, as seen above, this is not reciprocal, as no reference was made to the Portuguese jurisprudence by the Spanish Supreme Court. It is difficult to account for this difference, but one possible explanation could be that Portugal is a smaller country and therefore refers to a larger country in its judgments. Overall, some references were very laconic, made only in footnotes, ${ }^{124}$ while others properly engaged with the foreign judgment.

Finally, the data reveal that Denmark and Sweden did not refer frequently to one another in their case law. This is surprising given claims about a closely connected 'Nordic legal family', ${ }^{125}$ and their common history up until the 19th century. The 14 cross-citations by the Danish Supreme Court

happens behind the scenes). Since 2019 more extensive reasoning is required in some cases, for example, where there is a reversal of prior case law or the need of a proportionality test, see https://www.courdecassation.fr/IMG/NOTE\%20MOTIVATION\%2018\%2012\%202018.pdf.

117 See section 2, above.

${ }^{118}$ See also M. Requejo Isidro and M. Otero Crespo, 'Comparative Law Before the Spanish Private Law Courts in the XXI Century' in M. Andenas and D. Faigrieve, Courts and Comparative Law, p. 552, 558 who observe that the use of comparative reasoning is 'still not as common as it could, or even should, be'.

${ }^{119}$ See e.g. K. Zweigert and H. Kötz, An Introduction to Comparative Law (3rd edn, Clarendon, 1998), p. 107-8.

${ }^{120}$ For a study on foreign law influence in the reasoning of the Spanish Constitutional Court see P. Tenorio, 'El Derecho Comparado Como Argumento De Las Decisiones Del Tribunal Constitucional Español', 108 Revista Española de Derecho Constitucional (2016), p. 275. In the time period between 1980 and 2016, the Spanish Constitutional Court referred to foreign law on 51 occasions. The author explains that German and Italian law was most often referred to by the Spanish Constitutional Court given the considerable similarity of constitutional justice systems of these countries (see ibid., p. 303).

${ }^{121}$ A relative openness to engage with foreign case law has also been observed for the Portuguese Constitutional Court, see A.M. Guerra Martins and M. Prata Roque, 'Judicial Dialogue in a Multilevel Constitutional Network: The Role of the Portuguese Constitutional Court', in M. Andenas and D. Faigrieve, Courts and Comparative Law, p. 300.

${ }^{122}$ See e.g. K. Zweigert and H. Kötz, An Introduction to Comparative Law, p. 108-9.

123 Ibid.

${ }^{124}$ See e.g. the decision 1212/08.4TBBCL.G2.S1

${ }^{125}$ See e.g. J. Husa, K. Nuotio and H. Pihlajamäki (eds.) Nordic Law: Between Tradition and Dynamism (Intersentia 2008). See also U. Bernitz, 'What is Scandinavian Law? Concept, Characteristics, Future', 50 Scandinavian Studies in Law (2007), p. 13 (thus, excluding Finland). 
(Højesteret) are to Germany (3 citations), Sweden (3 citations), the Netherlands ( 3 citations), France (2 citations) and single citations to Finland, Italy and the UK. In the case of the Swedish Supreme Court (Högsta domstolen), the 16 cross-citations were split across Denmark (8 citations), Germany (3 citations), the UK (2 citations) and one each to France, Ireland and Austria. Hence, while the Nordic countries share a common history and - with the exception of Finland - a linguistic proximity, their supreme courts do not appear to form a close bond by way of citing each other. The low use of crosscitation between Nordic supreme courts might relate to the judicial style of court decisions in these countries, being relatively short and pragmatic and making little reference to academic sources. It also seems that Nordic cooperation might take other forms, such the drafting of common model laws and a shared political vision, ${ }^{126}$ rather than extensive judicial dialogue.

\section{E. 'Isolates'}

We have characterised the supreme courts of 8 countries as 'isolates'. These are the courts of Croatia, Estonia, Finland, Greece, Hungary and Romania (see Figure 6), as well Bulgaria and Latvia (not displayed in this figure, as will be explained). The defining characteristic of isolate courts is the low absolute number of cross-citations of any foreign higher courts (less than 10 cross-citations). ${ }^{127}$

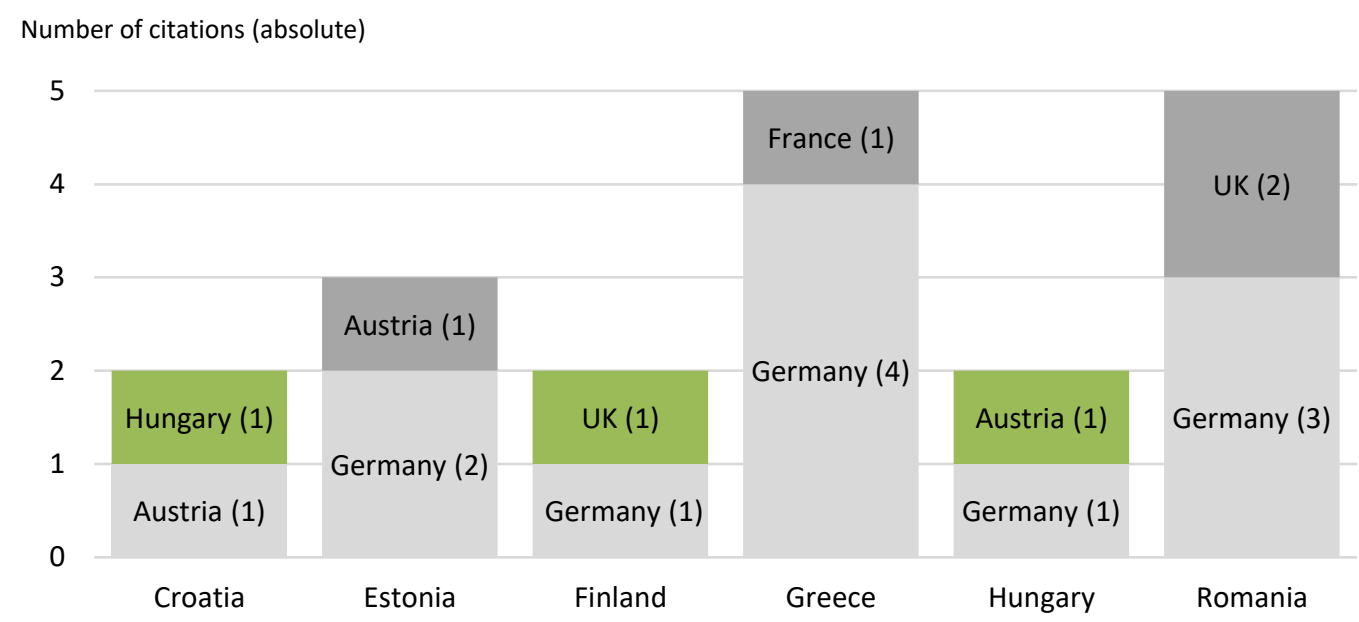

Explanatory note: following the classification scheme of Figure 1 (and different from Figures 2 to 5), this figure only refers to the absolute, not the relative, number of cross-citations

Figure 6. Cross-citations of the supreme courts of Croatia, Estonia, Finland, Greece, Hungary and Romania

In detail, there were 5 cross-citations by the Romanian Supreme Court (Înalta Curte de Casație și

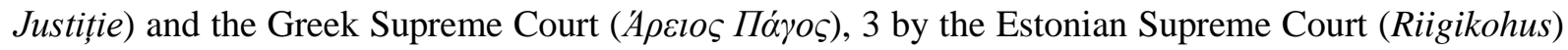
and two by the Finnish Supreme Court (korkein oikeus), the Hungarian Supreme Court (Kúria) and the Croatian Supreme Court (Vrhovni sud). No citations to foreign supreme courts have been identified in

\footnotetext{
${ }^{126}$ For the latter see in particular the contributions in P. Letto-Vanamo, D. Tamm and B.O. Gram Mortensen (eds.), Nordic Law in a European Context (Springer 2019) (referring to the Nordic welfare state, gender equality, forms of worker participation etc.).

${ }^{127}$ See section 2, above.
} 
the case-law of the Bulgarian Supreme Court (Върховен касационен съд) and the Latvian Supreme Court (Augstāka tiesa) ${ }^{128}$ Despite the modest number of cross-citations, isolates add a useful dimension to our discussion of geographical proximity, origins of legal tradition, judicial culture and language barriers as comparison parameters for the regional judicial dialogue between supreme courts.

The category of 'isolates' is geographically diverse, incorporating countries belonging to a number of European regions: the Baltics (Estonia and Latvia), the Nordics (Finland), Central Europe (Hungary) and Southeast Europe (Bulgaria, Croatia, Greece and Romania). Geographical proximity within these subgroups, however, says little about the cross-citation practices of the respective supreme courts. The supreme courts of the Baltic states do not cite each other but only cite supreme courts from Western European courts (for Estonia see Figure 6 and for Lithuania see Figure 5b in the previous sub-section). The Finnish court cited once the UK and German courts, but not any of the other Nordic courts (nor any of the Baltic ones). No cross-citations were identified between the Bulgarian and Romanian courts, with the German court again being the most frequently cited foreign court by the Romanian court (3 citations). Finally, neither Croatia nor Greece cite neighbouring foreign courts, with the Greek court again mainly citing the German court (4 citations).

As to the role of legal families, it is noteworthy that this category does not include any common law countries. However, its composition is highly heterogenous with respect to the origins of civil law tradition. At first sight, the category appears to be composed of civil law countries from the German tradition (Bulgaria, Estonia, Croatia, Greece, Hungary, Latvia). Yet, at a closer look, a significantly more nuanced picture emerges, as few of the above countries that undertook a civil law reform in the second half of the $20^{\text {th }}$ century strictly followed one single tradition. Examples are plenty: some Bulgarian private law statutes (notably contract law) were influenced by German law, yet others largely based on the French tradition; ${ }^{129}$ the Hungarian Civil Code of 1959 followed both Austrian and German traditions; ${ }^{130}$ the Croatian private law was in part influenced by Austrian and German (contract and property law) while other parts (principally property law) derived from Swiss and Italian law; ${ }^{131}$ the Baltic states also not only referred to German but Swiss and Dutch civil codes when replacing the Soviet era civil codes in the 1990s. ${ }^{132}$ The category, moreover, includes representatives of the French civil law tradition (Romania) ${ }^{133}$ and Nordic civil law (Finland).

Similar to the geographical subgroups, the shared civil law origins are not markedly reflected in the citation patterns. First, there are no citations of the French Supreme Court's case-law by the Romanian supreme court. The references to the case-law of the German Supreme Court, albeit more frequent within the countries following the German civil law tradition, have rather a sporadic nature. As we have seen above, although the German Supreme Court is the most frequently cited foreign court by the Estonian, Greek and Hungarian courts, the Bulgarian, Croatian and Latvian courts do not cite the German Supreme Court at all. Moreover, references from the Estonian, Greek and Hungarian courts are difficult to be

\footnotetext{
${ }^{128}$ For questions of public law, however, the Latvian court did cite some judgments of the German Constitutional Court. It is also worth quoting the Guidelines of the Latvian Supreme Court , available at http://at.gov.Iv/lv/jaunumi/par-tiesulietam/civillietu-departamenta/civillietu-departamenta-judikatura-un-tiesu-prakse-maija-klasifikatoros-pievienotinolemumi-10072, which state that ' 3 . Findings of foreign court rulings are not considered to be a main source of law in the Latvian legal system. Therefore, when referring to such a ruling, the judgment must state the reasons for its use based on the methodology of comparative law' (our translation).

${ }^{129}$ C. Takoff, 'The Present State of Harmonisation of Bulgarian Private Law, and Future Perspectives: Historical Development and Scope of the Private Law Compliance with European Private Law', 14 Juridica International (2008), p. 118.

${ }^{130}$ A. Kisfaludi, 'The Influence of Harmonisation of Private Law on the Development of the Civil Law in Hungary', 14 Juridica International (2008), p. 130.

${ }^{131}$ P. Lavický, J. Hurdík et al., Private Law Reform (Masaryk University, 2014), p. 119-21.

132 T. Kerikmäe et al. (eds.), The Law of the Baltic States (Springer International Publishing, 2017).

${ }^{133}$ See M. Gutan, 'Building the Romanian Modern Law - Why is it Based on Legal Transplant?', Acta Universitatis Lucian Blaga (2005), p. 130.
} 
compared to the citation patterns within other categories due to a scarcity of such references. Hence, the well-documented cross-border influence at the legislative level does not appear to extend to the judiciary.

Finally, it is possible to analyse this category of 'isolates' under the perspective of former Socialist bloc countries and the question of a possible Central and Eastern European (CEE) legal tradition. The majority of the countries in this category - six out of eight ${ }^{134}$ - had to reform many areas of private law after the dissolution of the Eastern or Socialist bloc. The legal reform in these countries in the last decade of the twentieth century has been largely facilitated by means of cooperation with Western European states and supranational organisations. ${ }^{135}$ Thus, property, contract, company and commercial law reforms have used Western European civil codes, including German, Dutch, French and Swiss codes, as models to amend or entirely replace redundant laws adopted in the Communist era. ${ }^{136}$ Despite the well-documented sources for the new civil law provisions originating from the German, Dutch or Swiss laws, a number of considerations might prevent the supreme court judges of the 'isolate countries' from referring to the case-law of the supreme courts of the countries from which these laws have been borrowed. Specifically, it is suggested that this limited dialogue can be framed as a set of factors defining the relative openness of legal cultures (e.g. legal borrowing and cooperation), on the one hand, and the lack of such openness of judicial cultures (e.g. the perception of the roles of judges), on the other hand.

The low degree of judicial openness shows, first, in the finding that there are close to no cross-citations between the supreme courts of the CEE countries discussed in this sub-section. Second, however, this only in part confirms the claim advanced by Giaro with respect to inadequacy of East-West divide in the discussion over European legal tradition. ${ }^{137}$ According to Giaro, 'the neighbouring eastern peripheries never communicate horizontally with each other, but always vertically with the centre, to which they constantly aspire. ${ }^{138}$ Yet, despite some references to the German Supreme Court by the 'isolates', the absolute number of such cross-citations is extremely low to provide a strong support for the second part of this claim.

Third, the absence of cross-citations between the CEE 'isolates' could be explained by reference to the roots of national civil laws that predate the Socialist period. In spite of the introduction of new civil codes in a number of former Socialist jurisdictions, these laws take their roots from an earlier period (1918-1939) when 'the intense circulation of western legal models throughout Eastern Europe' took place. ${ }^{139}$ Hence, the shared historical conditions and similarities in the process of civil law reform in

\footnotetext{
134 The exceptions are Greece and Finland.

${ }^{135}$ E.g. the role of the Foundation for International Legal Cooperation created by the Ministry of Justice of the Federal Republic of Germany in reforming Estonian property law; in case of Romania, the aid in the process of civil law reform from the Canadian Agency for International Development through the expert commission that drafted the Quebec Civil Code of 1991; on Estonia, see T. Kerikmäe et al., The Law of the Baltic States; Lavický et al., Private Law Reform, p. 213-4. More generally on the 'supply of law', see K. Pistor, The Evolving Legal Framework in the Former Socialist Countries (Columbia International Affairs Online (CIAO), 2002).

${ }^{136}$ See with respect of the Baltic states, T. Kerikmäe et al., The Law of the Baltic States. For Croatia see T. Josipović, 'Private Law Codification in The Republic of Croatia: An Example of Legal Reform in Post-Socialist Countries in South-East Europe', in W.-Y. Wang (ed.), Codification in International Perspective (Springer 2014), p. 107-23. On the need for reform in Hungary, see Lavický et al., Private Law Reform, p. 171-96.

137 T. Giaro, 'Legal Tradition of Eastern Europe: Its Rise and Demise', 2.1 Comparative Law Review (2011), available at http://www.comparativelawreview.unipg.it/index.php/comparative/article/view/45.

138 Ibid.

${ }^{139}$ Ibid, p. 19.
} 
these countries do not lead to a single model of 'CEE civil law jurisdictions', which would otherwise prompt an enhanced dialogue between their supreme courts.

Fourth, the lack of judicial openness (despite the openness of legal culture, especially legislatively) could be further explained by other factors affecting judicial dialogue. Such factors may be the traditional roles of judges, language barriers and, possibly also, accessibility of case-law. As regards the traditional roles of judges, elements of the 'survival' of the socialist legal tradition transposed throughout the judicial system (institutional continuity, appointment of judges and judicial argumentation) can constitute one obstacle to enhanced judicial openness. ${ }^{140}$ Language barriers constitute another obstacle, as none of the 'isolates' share the same language. ${ }^{141}$ Finally, the low number of cross-citations may be explained by domestic publication and reporting practices and the accessibility of supreme court judgments. These potential obstacles are analysed in the following section.

\section{Transparency and ease of access to supreme court decisions}

This section explains in detail the data collection process that forms the basis of this article. By way of an introduction, it is worth noting that accessing the judgments of the various supreme courts has occasionally been less straightforward than one would have expected (or hoped) in the contemporary digitalised world. Notably, although we were aiming to exclusively rely on freely available databases, we were not always able to do so. For instance, since different jurisdictions follow different practices with regard to the publication of the supreme courts' judgments, ${ }^{142}$ the full time period of interest (20002018) was not always available in these databases. In other instances, the recourse to subscription-based case law databases ${ }^{143}$ was mandated by the fact that the design of the freely available ones was coming with significantly limited search functions. ${ }^{144}$

In the following sub-sections, the different complexities that we have encountered will be explored with reference to specific examples. It should be noted, however, that the ease of access to court decisions is not merely a technical issue that is raised to highlight the challenges of our research endeavour. Instead, it is a matter intertwined with judicial transparency and thus, ultimately, with legal certainty and the promotion of the rule of law. ${ }^{145}$ The transparency of judgments also relates to judicial independence. This has become a thorny issue in the EU, ${ }^{146}$ as lack of such transparency can make it impossible to identify government interference in the judiciary. More generally, judicial transparency and easy access to prior judgments is crucial for the development of the law, in both common law and civil law countries. ${ }^{147}$ It is also illustrative that a number of voices refer to the 'human right' of access to legal

\footnotetext{
${ }^{140}$ See e.g. R. Mańko, 'Survival of the Socialist Legal Tradition? A Polish Perspective', 4.2 Comparative Law Review (2013), available at http://www.comparativelawreview.unipg.it/index.php/comparative/article/view/14.

141 This also applies to the two non-CEE countries in this group (Greece and Finland).

${ }^{142}$ For a comparative study on the publication of court decisions in EU Member States see M. van Opijnen et al., 'Online Publication of Court Decisions in Europe', 17 Legal Information Management (2017), p. 136.

${ }^{143}$ See further discussion in section 4.A, below.

${ }^{144}$ For several examples of such difficulties see section 4.C, below.

145 See e.g. S. Glassmeyer and P. Smith, 'Open Law: Technology in Service of the Rule of Law', 14 Legal Information Management (2014), p. 181, 182-3 (included references therein to the Declaration on Free Access to Law (the Montreal Declaration), available at http://www.falm.info/declaration/); G. Greenleaf, A. Mowbray and P. Chung, 'The Meaning of Free Access to Legal Information: A Twenty Year Evolution', 1 Journal of Open Access to Law (2013), p. 1, 57.

${ }^{146}$ See e.g. D. Adamski, 'The Social Contract of Democratic Backsliding in the "New EU" Countries', 56 Common Market Law Review (2019), p. 623.

${ }^{147}$ For the different role of precedent in civil and common law systems see e.g. A. Shoenberger, 'Changes in the European Civil Law Systems: Infiltration of the Anglo-American Case Law System of Precedent into the Civil Law System', 55 Loyola Law Review (2009), p. 5; R. Camarena González, 'From Jurisprudence Constante to Stare Decisis: the Migration of the Doctrine of Precedent to Civil Law Constitutionalism', 7 Transnational Legal Theory (2016), p. 257.
} 
information, ${ }^{148}$ while the publication of judgments raises also data protection issues that may need to be addressed (e.g. through anonymisation). ${ }^{149}$

\section{A. Sources of case law}

When searching for case law of supreme courts in the 28 EU Member States in the 2000-2018 period, we used a variety of types of online databases. The list of these databases was already displayed in Table 1 , at the beginning of this article. ${ }^{150}$ It should be noted that this table did not aim to provide a comprehensive overview of all databases available in each Member State. Instead, it lists the database, or a combination thereof, that we have used in each state and that provides the most easy-to-search and comprehensive access to the case law in the studied period. ${ }^{151}$ In addition, Table 1 included two further pieces of information: first, the originator of the database namely whether it is a public body - be it competent government ministries, the courts themselves, or any other state bodies - or a private entity; and, second, its accessibility, i.e. whether the database is freely available or a subscription is needed. Table 2 summarises these two further aspects.

Table 2. Originators and need for subscription of databases used in this study $y^{152}$

\begin{tabular}{|l|l|l|}
\hline & Subscription not needed & Subscription needed \\
\hline Public originator & $\begin{array}{l}\text { Austria, Belgium, Croatia, Czech Rep., } \\
\text { Denmark, Estonia, France (LegiFrance), France } \\
\text { (Cour de Cassation), Germany, Greece (Areios } \\
\text { Pagos), Hungary, Latvia, Lithuania, } \\
\text { Luxembourg, Malta, Netherlands, Poland (Sąd } \\
\text { Najwyższy), Portugal, Romania, Slovakia, } \\
\text { Slovenia, Spain, Sweden }\end{array}$ & \\
\hline $\begin{array}{l}\text { Private, non- } \\
\text { commercial } \\
\text { originator }\end{array}$ & Cyprus, Ireland, UK & $\begin{array}{l}\text { Greece (DSA Isokratis) [free } \\
\text { for members of the Bar only] }\end{array}$ \\
\hline $\begin{array}{l}\text { Private, } \\
\text { commercial } \\
\text { originator }\end{array}$ & Finland & $\begin{array}{l}\text { Bulgaria, Greece (Nomos), } \\
\text { Italy, Poland (LEX) }\end{array}$ \\
\hline
\end{tabular}

${ }^{148}$ For the access to legal information as a human right see L.E. Mitee, 'The Right of Public Access to Legal Information: A Proposal for Its Universal Recognition as a Human Right International Jurisprudence', 18 German Law Journal (2017), p. 1429; S.D. Jamar, 'The Human Right of Access to Legal Information: Using Technology to Advance Transparency and the Rule of Law', 1 Global Jurist (2001), p. 1.

${ }^{149}$ See M. Bobek, 'Data Protection, Anonymity and Courts', 26 Maastricht Journal of European and Comparative Law (2019), p. 1; P. Magrath, 'Transparency, Data Protection and the Law Courts of the Future', Legal Information Management (2018), p. 70.

${ }^{150}$ See section 2, above.

${ }^{151}$ For instance, there are public databases of case law of the Irish Supreme Court (https://www.courts.ie/ judgments) and the UK Supreme Court and House of Lords (https://www.supremecourt.uk/decided-cases/index.html and https://publications.parliament.uk/pa/ld/ldjudgmt.htm). But because BAILII is more comprehensive (Ireland) and includes a superior search function (UK), we have opted to use the latter.

${ }^{152}$ For the list of databases see Table 1 in section 2, above. 
As Table 2 demonstrates, an overwhelming majority of the databases we have used to collect a comprehensive sample are public and accessible free of charge. Other than the private databases we have used in Bulgaria, Greece, Finland, Ireland, Italy, Poland and the UK, all databases originate from public bodies. Additionally, other than the commercial databases in Bulgaria, Greece, Italy and Poland, which are subscription-based, all other databases we have used are available without subscription. ${ }^{153}$ In the cases of Bulgaria, Greece, Poland and Italy, a subscription to private databases was needed to access older case law. ${ }^{154}$ In Poland and Greece, like the UK and Ireland, private databases were preferred due to their superior search function. ${ }^{155}$ In Italy as well, a private subscription-based database was used to search the entirety of the studied period, even though jurisprudence since 2009 is freely available from a private database and case law of the last five years is available on the official website of the Corte Suprema di Cassazione. ${ }^{156}$ Thus, since 2015, all case law of supreme courts in all EU Member States can be freely accessed in public databases.

This is in line with the move in the legal information market in the past decades away from strong commercial players ${ }^{157}$ towards enabling free access to all legal materials to everyone as advocated for by various Open Law initiatives, ${ }^{158}$ the academic discourse, ${ }^{159}$ legal practitioners,,${ }^{160}$ as well as by various European actors. ${ }^{161}$ The EU, in particular, has provided strong financial support for the establishment of public databases of case law. Through its Horizon 2020 programme, it funds the 'Common Portal of Case Law', which integrates databases of most Member States' supreme courts into a single search engine. ${ }^{162}$ It also provided funding for the establishment of many domestic public databases, including the recently renovated Croatian, Slovenian, and Maltese databases. ${ }^{163}$ Through this, the EU has contributed to the establishment of the European landscape of legal informatics we live in today - one

153 BAILII, in cases of Ireland and the UK, is a private database but not a commercial one as it provides free access.

${ }^{154}$ In Bulgaria, a subscription was needed to access pre-2008 case law; in Greece, for jurisprudence before mid-2006; in Italy, for jurisprudence from before 2009; in Poland, for more comprehensive to case law of the early 2000s.

${ }^{155}$ For more details see section 4.C, below.

${ }^{156}$ See http://www.italgiure.giustizia.it/sncass/.

157 Van Opijnen et al., 17 Legal Information Management (2017), p. 139; C.S. Fellows, Philip Leith and Joe Ury, 'Assessing BAILII in 2012', 12 Legal Information Management (2012), p. 158, 158-59; P. Leith and C. Fellows, 'Enabling Free OnLine Access to UK Law Reports: The Copyright Problem', 18 International Journal of Law and Information Technology (2010), p. 72; E.A. Ontanu and M. Velicogna, 'EU Judicial Procedures and Case Law Databases: What's Going on and What May Lay Ahead?', in G. Peruginelli and S. Faro (eds.), Knowledge of the Law in the Big Data Age (IOS Press 2019), p. 251.

${ }^{158}$ S. Glassmeyer and P. Smith, 'Open Law: Technology in Service of the Rule of Law', 14 Legal Information Management (2014), p. 181; T.K. Armstrong, 'Crowdsourcing and Open Access: Collaborative Techniques for Disseminating Legal Materials and Scholarship’ 26 Santa Clara Computer \& High Technology Law Journal (2009), p. 591.

${ }^{159}$ L.E. Mitee, 18 German Law Journal (2017), p. 148. For a slightly different view, see G. Greenleaf et al., 1 Journal of Open Access to Law (2013), p. 30.

${ }^{160}$ C.S. Fellows et al., 12 Legal Information Management (2012), p. 162.

${ }^{161}$ See e.g. Council of Europe Recommendation No. R(83) 3 of the Committee of Ministers to Member States concerning the Protection of Users of Computerised Legal Information Services of 22 February 1983 and Council of Europe Recommendation No. R(95) 11 of the Committee of Ministerst to Member States Concerning the Selection, Processing, Presentation and Archiving of Court Decisions in Legal Information Retrieval Systems of 11 September 1995.

162 Accessible at https://network-presidents.eu/cpcl/search_engines. So far, it integrates databases of the supreme courts of Austria, Belgium, the Czech Republic, Cyprus, Germany, Estonia, Finland, France, Croatia, Hungary, Luxembourg, Portugal, Romania, Sweden, Slovenia, UK, and Ireland. Jurisprudence of the Supreme Court of Liechtenstein is also included.

${ }^{163}$ In Croatia, all Supreme Court decisions since 1990 have been published in an online database since late 2010 as a result of the European PHARE 2006 Harmonisation and Publication of Case Law project, worth almost 1.5 million EUR. See https://pravosudje.gov.hr/pristup-informacijama-6341/ostale-informacije/projekti/eu-projekti/dovrseni-projekti/6211. Similarly in Malta, $80 \%$ of the project funds needed for the establishment of the eCourts database were guaranteed by the EU. See https://ecourts.gov.mt/onlineservices/. 
that has liberated itself from the monopolies and oligopolies of private publishers of the past, towards a present and a future in which legal materials, including jurisprudence of supreme courts, are available for anyone to consult openly.

\section{B. Completeness}

In most cases, the full studied period (2000-2018) was available in the national databases, with the exceptions of Denmark (available from September 2009), Luxembourg (from 2002) and Malta (from 2001). However, many databases featured significantly fewer decisions from the early 2000s: this was the case for the databases of the Czech Republic, Luxembourg, Poland, Romania and Slovakia. ${ }^{164}$

The question is whether this is due to the lower workload of the highest courts in the early 2000s or due to the fact that there was less reporting and that fewer decisions were digitalised at the time (or a combination of both). As indicated previously, in the great majority of cases, the numbers of the decisions available in the databases corresponded roughly to the number of decisions listed on the CEPEJ database. ${ }^{165}$ Nevertheless, in many cases, it was unclear whether the national database featured all the decisions from 2000 to 2018 or if only a selection of decisions appeared. The German database states explicitly that all decisions from 1 January 2000 are available in the database. In other cases, the uncertainty is not easily resolved as neither the website of the supreme court nor the database asserts whether the database is complete or not. Additionally, no information could be found in the literature as to whether the database was complete or not (this was the case, for instance, for the Czech Republic, Hungary, Greece, Portugal and Spain). In Slovakia, the literature reveals that until the second half of 2008 the vast majority of decisions were not publicly accessible. ${ }^{166}$ In other cases, vague formulations make it hard to estimate to which extent the database is complete. The BAILII database for the Irish Supreme Court states that the database is 'reasonably comprehensive' from February 2001, while the Swedish one claims to contain only 'guiding decisions'. ${ }^{167}$ Hence, we have identified not only a problem of completeness but also of transparency as to whether the database is complete or not. ${ }^{168}$ An effort for transparency was made by the Polish Supreme Court in an order of its President in 2012 stating that all decisions after 2003 must be published on the electronic database of the Court (with the exception of decisions in which the Supreme Court refused to accept the cassation complaint for consideration). ${ }^{169}$ It also seems that, in some cases, the database is updated gradually, and that recent judgments might not have all been added on the database. ${ }^{170}$

\footnotetext{
${ }^{164}$ For example, in the Supreme Court of the Czech Republic, 1670 cases were resolved in 2000, while 5717 in 2018 ; in Romania, very few cases were reported in 2000 and 2001 on the website of the highest court; in Luxembourg, the database of the Supreme Court features 22 decisions in 2002 and 156 in 2018.

${ }^{165}$ See section 2, above.

${ }^{166}$ See M. Bobek, Comparative Reasoning in European Supreme Courts, p. 185-6.

${ }^{167}$ See https://rattsinfosok.domstol.se/ ('vägledande avgöranden').

${ }^{168}$ Also in many cases, as mentioned earlier, the problem is accentuated by the fact that a private database is needed to access all the court decisions (such as in Bulgaria, Cyprus, Greece, Ireland, Italy and the UK).

169 Order of the President of the Supreme Court of 10 April 2012, available in Polish at http://www.sn.pl/Aktualnosci/SiteAssets/Lists/Aktualnosci/NewForm/Zarz_PP_SN_11_2012.pdf.

${ }^{170}$ For example, for the Greek Supreme Court, 2040 judgments were available for the year 2017 in 2019, while 2139 were featured on the same database in 2020.
} 
Specifically, we also examined two further aspects: (i) whether advocate general (AG) opinions were available in the examined databases (if applicable), and (ii) whether the courts issued single, consolidated judgments, and if not, whether individual opinions delivered by judges were freely and fully available in the databases. Four of the EU Member States (Belgium, France, Luxembourg and the Netherlands) have a system of advocates general that assist the decision making of the national supreme courts. ${ }^{171}$ Yet, only the Dutch court made the full text of all AG opinions publicly available. In the case of Belgium, the availability of AG opinions was only partial, or rather, it was unclear whether all AG opinions were available, as in some cases these were placed in the 'summary' field of the final judgment. In the case of the French court, the accessibility of AG opinions was lower through the database than through a simple Google search, as the used database required a separate search for judgments and opinions. Finally, the Luxemburg court informed us that it does not make AG opinions available for confidentiality reasons (even though AG opinions were issued as per the court's functioning). ${ }^{172}$

As regards the second aspect, we established that 25 of the scrutinised supreme courts issued single opinions (that is, one consolidated judgment), whereas two supreme courts published the individual judgments delivered by the judges sitting on the bench. These three cases are the UK, Ireland and Cyprus, which is in line with the general insight that common law courts are more likely to feature such individual judgments. ${ }^{173}$ By contrast, the Maltese supreme court which, in some respects, can also be considered to be a common law jurisdiction, ${ }^{174}$ only issues single opinions.

\section{Search functions}

The vast majority of the websites used for this study can be described as user-friendly and functional, allowing the identification of relevant judgments without major technical difficulties. ${ }^{175}$ That said, however, we encountered some limitations with the search functions of several search engines. For example, the website of the Dutch Supreme Court, albeit easy to navigate, did not enable the search for alternatives (in the form of 'or' searches). The Slovakian search engine did not allow the selection of results for both the Commercial and the Civil Law Division at the same time. In the case of the Luxembourgish Supreme Court, the search function provides only a blank search form for a word-search without any additional filters.

There were also several cases where the limitations of the search functions were of a different gravity. For example, the Hungarian website was not user-friendly, in particular with regard to the nontechnologically advanced keyword search function, which was leading to false positives. The Portuguese database also turned out to be rather hard to navigate, since it was not possible to narrow

${ }^{171}$ For a historic comparative outlook on the various systems of advocates general in place in European court systems see M. Bobek, 'A Fourth in the Court: Why are there Advocates-General in the Court of Justice?', 14 Cambridge Yearbook of European Legal Studies (2011-2012), p. 529; K. Borgsmidt, 'The Advocate General at the European Court of Justice: A comparative study', 13 European Law Review (1988), p. 106.

172 During the course of our research, we were in contact with the Adjoint General President of the Court of Cassation of Luxembourg, who was open to granting us the possibility of consulting the court's archives in Luxembourg upon the signature of a confidentiality agreement. This would have required the court to perform a preliminary search with key terms in order to select the decisions relevant for our study and to anonymise these. However, in light of the involved efforts on part of the court and the limited potential benefit to our research, we kindly turned down this opportunity.

${ }^{173}$ For a gripping overview of the complexity of majority, dissenting and concurring opinions in the judicial systems of common and civil law jurisdictions see Lord Justice Mance 'The Common Law and Europe: Differences of Style Or Substance and Do They Matter?', Presidential Address to the Holdsworth Club of the University of Birmingham, 26 November 2006, available at https://www.birmingham.ac.uk/Documents/college-artslaw/law/holdsworthaddress/holdsworth06-07-mance.pdf and M. Kirby, 'Judicial Dissent - Common Law and Civil Law Traditions', 123 Law Quarterly Review (2007), 379.

${ }^{174}$ See section 3.B, above.

175 The website of the Belgian Supreme Court could, however, only be consulted after installation of an additional flash player plug-in. 
down the results to private law cases and to determine the timespan. ${ }^{176}$ The greatest difficulties concerned the French website which does not provide a general search function for several chambers. Thus, the search was performed entirely through Google. In this way, while not entirely straightforward, it was possible to identify the relevant judgments of the French court and sort them out of the multiple false negatives by focusing on the files in PDF format.

As for other countries, our attempts to run the search for foreign references in the supreme court judgments through Google in order to verify and/or refine our search results led to mixed results. In some cases, for example Austria, Hungary, Italy, Luxemburg and Bulgaria, Google did not prove useful in improving the results of the search through dedicated court websites. In most cases, it simply redirected to the official database. In Estonia and Latvia, the benefits of searching through Google were limited, as only court decisions available on the webpage in summaries appeared. For some countries, for instance the Netherlands and Cyprus, the results seem under-inclusive, compared to the ones of the search engines of the courts' portals. In the case of Ireland and the UK, a 'Google-search' could not be performed as the BAILII database prohibits search engines to index judgments. In the case of Belgium, due to the already mentioned access through a plug-in, searching through Google was not possible. For a number of countries, ${ }^{177}$ Google did, in principle, allow for searching the court judgments; however, it was neither more practical nor more inclusive than directly through the official websites.

As our research aimed to identify the cross-citations in matters of private law only, an important part of the inquiry was to reduce the results to private law cases. In the majority of databases, it was possible to safely divide the search into private law and non-private law cases as the search function allowed a differentiation between court divisions (or areas of law) or as the judgments themselves included such information. ${ }^{178}$ However, in some instances, the databases/judgments did not allow such a clear division. For example, in the cases of the supreme courts of the UK, Ireland and Cyprus (when using the public 'cylaw' database), the nature of the matter sub judice (private, criminal or other) could only be safely identified by reading through the case. In a few other instances, although the database in principle offers the possibility to limit the search results to private cases only, it was either not possible to combine this feature with other filters (e.g. term-search) ${ }^{179}$. Also, in some instances, there were reasonable doubts as to the accuracy of the results and the effectiveness of the filter. ${ }^{180}$ Thus, often, the lack of an option to reliably narrow down the search to cases dealing with private law matters meant that we verified each judgment that contained a cross-citation by hand in order to exclude non-private law cases.

Some of the problems with identifying all references to foreign supreme court judgments were also directly related to the limitations of the search functions. For example, the website of the Spanish Supreme Court produced many false positives, unless the search term was put in inverted commas to show only the exact results. This method required great precision. For example, the results from

\footnotetext{
${ }^{176}$ It should be noted that the new database, operating since 1 January 2020, appears more user-friendly than the previous one and it offers more advanced filters. Our data has been, however, collected prior to the launch of this website.

${ }^{177}$ E.g., Denmark, Finland, Greece, Lithuania, Sweden.

178 This was the case for Austria, Croatia, the Czech Republic, Estonia, Finland, Germany, Greece, Latvia, Lithuania, Malta, the Netherlands, Poland, Romania, Slovakia, Slovenia and Spain.

${ }^{179}$ E.g. in the case of the French court, the research was performed through Google and it was, therefore, impossible to apply any additional filters. Portugal also falls in this category.

${ }^{180}$ For example, in the case of Hungary, it was possible to search only for private law cases (picking the field of law from a drop-down menu). Nevertheless, the general shortcomings of the search engine were such that we could not rely on this functionality of the filtering for private law cases. Other examples in this category are Austria and Belgium.
} 
searching ‘Tribunal Supremo Federal Alemán', did not include references to 'tribunal federal alemán' - both of which were valid for our data collection. On the portal of the Supreme Court of Belgium, there was no reliable option to search for a given word specifically. Filtering out the cases relevant for our study required going through many false positives (e.g. results containing 'François' instead of 'Français').

Further problems did not relate to the search functions per se, but rather to the way in which judgments of a given country are typically cited. This was an issue with the references made to the UK Supreme Court (and previous decisions of the House of Lords), which was most problematic in searching for references made by the supreme courts of Ireland, Malta and Cyprus. Sometimes the citation includes 'UKSC' or 'UKHL' which will clearly indicate that the case was from the Supreme Court (UKSC) or the House of Lords (UKHL). But more often than not, a UK case will simply be cited on the basis of the law report in which it was published, e.g. using 'WLR' or 'All.ER', which can also cover UK judgments other than those from the UK Supreme Court (or previously the House of Lords). Thus, the only way to establish whether a cited case is a UKSC/UKHL case, or a case from any lower English court, was to manually look up every single case that is cited in a given decision. Since doing such searches for all ambiguous results was not feasible, we took a sample of twenty cases of which we thought might contain many false positives and then inferred a total number of citations from there.

More generally, another impediment to the identification of all judgments falling within the scope of our study relates to the reference style of the supreme courts. Searching for foreign citations was easier for the courts which tend to cite foreign judgments using the original names of the supreme courts and/or their common abbreviations rather than the translations. This was an effective method for instance for the judgments of the German Supreme Court. It typically uses the full foreign name of the supreme courts it referred or their abbreviation (e.g. 'OGH' for the Austrian Supreme Court). The same is true for the Netherlands and the Czech Republic. More often, though, few results were found this way, as the courts preferred to use solely the translated names. Thus, we also searched for the translated names of the supreme courts, often using multiple variants. To give an example, in English, German Bundesgerichtshof could be found under 'German Supreme Court', 'Federal Supreme Court of Germany', 'German Federal Tribunal', 'Federal Tribunal of Germany' etc., and the French Cour de Cassation could be referred to, among others, as the 'French Supreme Court', 'French Cassation Court', 'French Cassation Tribunal', 'Cassation Court of the French Republic' etc.

The search for foreign court references with translated terms was even more complex in the case of some countries which have deflections (e.g. Slavic languages). Accordingly, search for the references made by the supreme courts of the Czech Republic, Slovakia, Slovenia and Poland required checking the forms in nominative, genitive and accusative. This factor might have contributed to some false negatives which were not identified in our research. In addition, in a few instances the foreign name of the supreme court cited was not used in its original form, but only its translation or abbreviations of the translation. In that category, we quote indicatively, Poland and the fact that the Polish grammar has noun declension. It was therefore necessary to check the Polish names of foreign courts not only in nominative (e.g. 'Niemiecki Trybunał Federalny' or 'niemiecki Sąd Najwyższy'), but also in genitive (e.g. niemieckiego Trubunału Federalnego or 'niemieckiego Sądu Najwyższego'). This made this search more complex. Notably, in the case of Poland, commercial databases (e.g. lex.pl) are more flexible as, even if one searches the term in nominative, the results showing this term in other cases will appear as well. By way of an example, searching for references made by the Polish Supreme Court to the Austrian Supreme Court ('austriacki Sąd Najwyższy') would give 1 result on the public database, and 7 results on the commercial one, for the same time period and Chamber.

Moving on to other issues that might have impacted on the reliability of the results, a reference to the search engine of the Supreme Court of Romania shall be made. During our research through the database, we had inadvertently found the judgments in which the Romanian Supreme Court refers to 
BGH as 'Curtea Federală din Germania' ${ }^{181}$ But when we searched for this exact term that was used in the judgment we had found by chance ('Curtea Federală din Germania'), the search engine provided no results. Thus, it is likely that our research on Romanian citation patterns suffers from some false negatives on account of a suboptimal search function.

Overall, the issues about the transparency and ease of access of supreme court decisions discussed in this section offer a mixed conclusion. Using various databases and search techniques, it has been possible to collect information about cross-citations from all the 28 supreme courts under investigation. Yet, for some courts, even the best sources and techniques face the limitation that the courts produce very short judgments with any possible foreign influence being left unmentioned (and thus the court not being transparent about it). ${ }^{182}$ In addition, some limitations in terms of completeness and search functions were identified in this section. While many of those limitations could be overcome, for instance, by way of checking citations by hand, it would be helpful for both research and practice if courts were to address these limitations.

\section{Conclusion}

Comparative law is often said to have a bias in terms of focusing on topics of private law. ${ }^{183}$ In the EU, the harmonisation of many topics of private law also has the aim to contribute to the creation of a common market. ${ }^{184}$ Thus, it may be expected that judicial dialogue in private law is a frequent phenomenon in the EU today, in particular as far as the application of harmonised rules is concerned. ${ }^{185}$ While judicial dialogue may take many forms, cross-citations between courts from different countries could be a visible sign of such influence of comparative legal information.

However, the findings of this article offer a mixed result as to the nature and frequency of cross-citations between supreme courts in private law in the EU. Only in few instances, we found a reciprocal relationship between the supreme courts of two countries (e.g. the Czech Republic and Slovakia). More generally an asymmetric picture emerges, particularly as far as the relationship between larger and smaller jurisdictions is concerned. Specifically, this article provided a taxonomy that distinguished between the categories of 'true followers', 'true comparatists', 'reluctant followers', 'reluctant comparatists' and 'isolates'. The distinctions between supreme courts that cite mainly one country and those that cite more widely were found to be plausible as the former courts were from countries whose legal system has been strongly influenced by the other country. The distinctions according to the frequency of cross-citations were more difficult to explain. For the cases with many cross-citations, we often found that a common language is a key explanatory factor. By contrast, we did not find that the

\footnotetext{
${ }^{181}$ Namely in the judgment Decizia nr. 1742/2016.

${ }^{182}$ See sections 3.C to 3.E, above, in particular on the Romanistic and Nordic civil law countries as well as many (though not all) countries of Central and Eastern Europe.

${ }^{183}$ E.g., U. Mattei, 'The Cold War and Comparative Law: A Reflection on the Politics of Intellectual Discipline', 85 American Journal of Comparative Law (2017), p. 567, 572; H. Pihlajamäki, 'Merging Comparative Law and Legal History: Towards an Integrated Discipline', 66 American Journal of Comparative Law (2018), p. 733, 739.

184 See section 1 , above.

${ }^{185}$ For a similar argument see German Supreme Court, BGH GRUR 2010, 950 (Walzenformgebungsmaschine) requiring German courts to consider the case law of other contracting states concerning the application of the European Patent Convention; UK and French courts also use foreign case law in this area, see references in Karen Walsh, 'Promoting Harmonisation Across the European Patent System Through Judicial Dialogue and Cooperation', 50 International Review of Intellectual Property and Competition Law (IIC) (2019), p. 408, 425-9.
} 
frequency of cross-citations simply follows the divide between legal families, while we did observe that many of the 'isolates' were civil law countries from Central and Eastern Europe. It also seems likely that the general judicial style of some of the supreme courts means that they write fairly short decisions, or else refrain from non-essential citations, with the result that citations of foreign courts do not feature frequently.

These instances of few cross-citations may also partly be due to the limitations of transparency and ease of access of supreme-court decisions identified in the latter part of this article. While most of the supreme courts have made their decisions freely available online, we also identified some gaps as well as practical problems in the search functions of the available databases. This is not only a limitation for gaining valuable comparative information, but also a concern for judicial transparency in general and the function of judicial dialogue for EU integration in particular. In order to remedy this situation, some of the ongoing EU measures, for instance, an EU-wide system of Case Law Identifiers and a common database of case law can be helpful. ${ }^{186}$ Yet, it is also clear that a more comprehensive use of crosscitations in the EU will only emerge if judges and lawyers perceive themselves as forming part of a common European legal culture. Thus, while the topic of cross-citations seems to be of a specific nature, understanding its current patterns is also a litmus test for European legal integration. 
